SJ Quinney College of Law, University of Utah Utah Law Digital Commons

8-2020

Chapter 20 - Technical Standards: Fair, Reasonable and NonDiscriminatory (FRAND) Licensing

Jorge L. Contreras

Follow this and additional works at: https://dc.law.utah.edu/scholarship

Part of the Intellectual Property Law Commons 


\section{Chapter 20 - Technical Standards: Fair, Reasonable and Non-Discriminatory (FRAND) Licensing ${ }^{1}$}

\section{Chapter Contents}
A. Standards, Standardization and Patents
B. Patent Disclosure Policies
C. FRAND Royalty Rates
D. Non-Discrimination and FRAND Commitments
E. Effect of a FRAND Commitment on Injunctive Relief
F. The Transfer of FRAND Commitments

\section{A. Standards, Standardization and Patents}

Technical standards like Wi-Fi, 3G/4G/5G, Bluetooth and USB enable devices made by different manufacturers - whether laptops, smartphones, automobiles or heart monitors - to communicate with very little effort by the end user. Today, these standards impact virtually all aspects of the modern networked economy. The existence of these standards, and the widespread product interoperability that they enable, give rise to significant market efficiencies known as "network effects." Such standards can increase innovation, efficiency, and consumer choice; reduce barriers to market entry; foster public health and safety; and enable efficient and reliable international trade. As the Ninth Circuit has observed, "[w] hen we connect to WiFi in a coffee shop, plug a hairdryer into an outlet, or place a phone call, we owe thanks to standard-setting organizations."2

\section{THE GREAT BALTIMORE FIRE AND STANDARDS}

The critical importance of interoperability standards is illustrated by the tragic story of the 1904 Baltimore fire. At the outbreak of the fire, which portended to be large, fire crews were called in from as far away as Washington, D.C. But when they arrived, the crews discovered that their fire hoses could not be coupled to the fire hydrants in Baltimore due to differences in shape, diameter and thread count. As a result, the fire fighters stood by helplessly as more than seventy city blocks were destroyed.

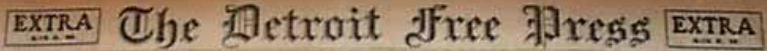

$$
\begin{aligned}
& \text { BALTIMORE IS BENG SWEPT BY FIRE! } \\
& \text { FIREMEN ARE HELPLESS } \\
& \text { TO CHECK THE FLAMES FOR RUSSIA'S REPLY }
\end{aligned}
$$

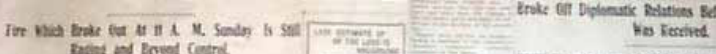

\footnotetext{
${ }^{1}$ This Chapter deals with the contractual, pseudo-contractual and governance issues raised by technical standard setting. Antitrust issues associated with standards development are discussed in Chapters 25 (Antitrust and Competition Issues) and 27 (IP Pools and Aggregators).

${ }^{2}$ Microsoft Corp. v. Motorola, Inc., 795 F.3d 1024 (9 $9^{\text {th }}$ Cir. 2015).
} 


\section{The SDO Ecosystem}

Most of the technical standards currently deployed throughout the world were developed collaboratively by market participants in voluntary standards-development organizations (SDOs, sometimes referred to as "standard-setting organizations" or SSOs). SDOs range from large, governmentally-recognized bodies that address a diverse range of standardization projects (e.g., the International Organization for Standardization (ISO)), to established private sector groups that address the standardization needs of major industry segments (e.g., the European Telecommunications Standards Institute (ETSI), Internet Engineering Task Force (IETF), and Institute for Electrical and Electronics Engineers (IEEE)) to smaller groups often referred to as "consortia" that focus on one or a handful of related standards (e.g., the HDMI Forum, Bluetooth Special Interest Group, USB Forum). Because of the significant market benefits that are made possible by technical standards, a high degree of cooperation among competitors has long been tolerated by antitrust and competition law authorities, which might otherwise discourage such large-scale coordination efforts among competitors. ${ }^{3}$

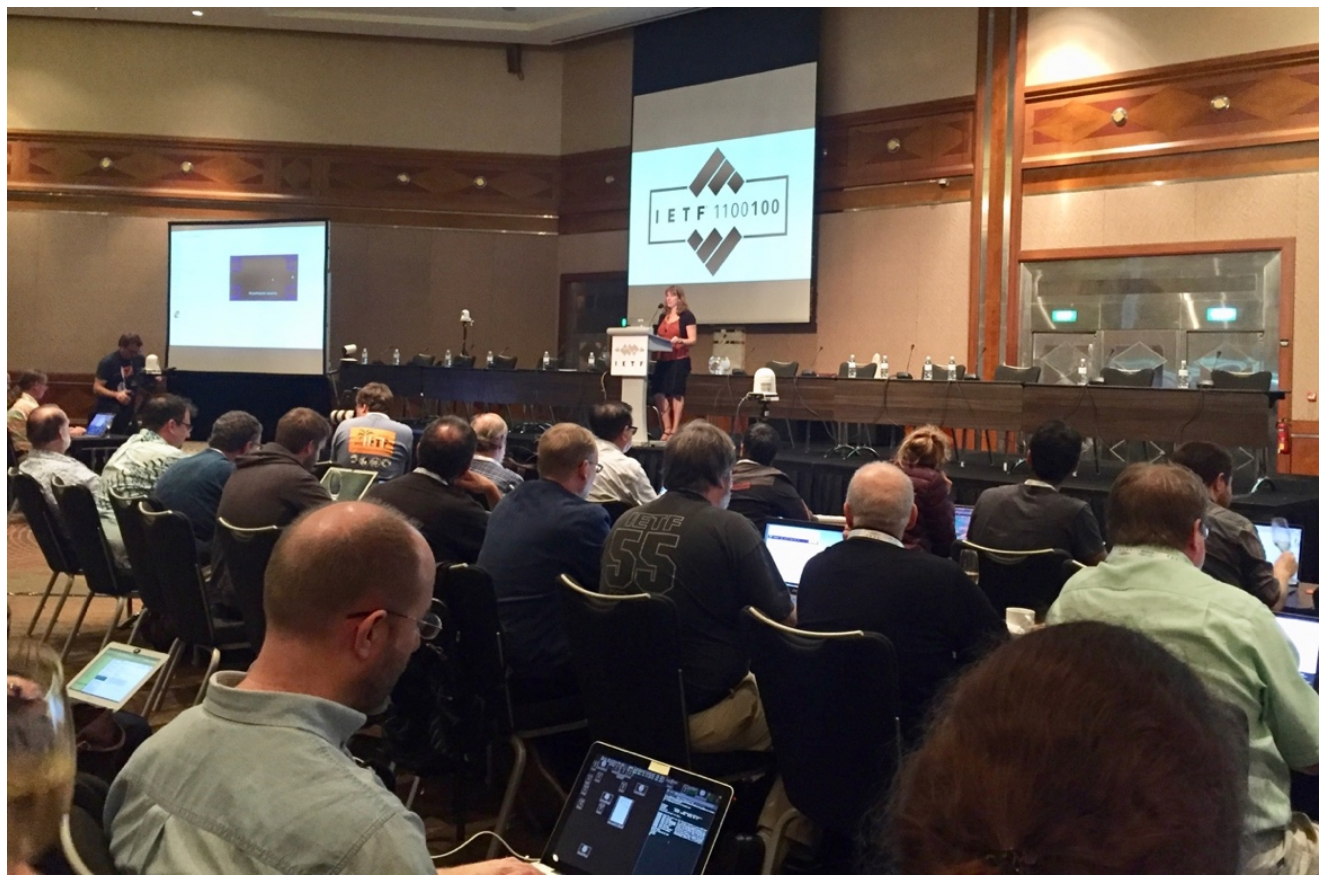

A 2017 meeting of the Internet Engineering Task Force (IETF) [photo: the author]

\footnotetext{
${ }^{3}$ See Chapter 25, Part H, for a discussion of antitrust issues and due process requirements for SDOs.
} 


\section{Patents and Standards}

Many of the technological features specified by standards can be patented. Such patents are typically obtained by those participants in a standardization activity that make technical contributions to the standard (SDOs themselves almost never obtain patent protection over their standards). However, to the extent that patents cover technologies that are "essential" to the implementation of a standard ("standards-essential patents" or "SEPs"), concerns can arise.

Ordinarily, if the manufacturer of a product that allegedly infringes a patent is unable, or does not wish, to obtain a license on the terms offered by the patent holder, the manufacturer has three options: stop selling the infringing product, design around the patent, or do neither and risk liability as an infringer. With standardized products, however, the manufacturer's choices are more limited, as designing around the patent may be impossible or may make the product non-compliant with a commercially necessary standard (e.g., who would sell a smartphone today without Wi-Fi capability?). Moreover, once a standard is approved and released by an SDO, manufacturers may make significant internal investments on the basis of the standard. In such cases, the cost of switching from the standardized technology to an alternative technology may be prohibitive (a situation often referred to as "lock-in"). Once manufacturers are locked into a particular standardized technology, the holders of SEPs covering that technology may be able to extract fees that exceed the value of their patented technology, simply because the manufacturer is unable to switch to an alternative technology without incurring substantial costs. As explained by the Ninth Circuit, "The tactic of withholding a license unless and until a manufacturer agrees to pay an unduly high royalty rate for an SEP is referred to as "hold-up."'4

The risk of hold-up is likely to increase as the number of parties holding SEPs covering a single standard rises. Complex technological products may implement dozens, if not hundreds of standards, each of which may be covered by hundreds or thousands of patents held by a wide range of parties. As such, the aggregation of royalty demands by multiple patent holders could lead to high costs on implementing standards-compliant products. This situation is sometimes referred to as "royalty stacking". Royalty stacking can arise "when a standard implicates numerous patents, perhaps hundreds, if not thousands," each of which bears a royalty that must be paid by product manufacturers and which "may become excessive in the aggregate." When royalty stacking occurs, "(1) the cumulative royalties paid for patents incorporated into a standard exceed the value of the feature implementing the standard, and (2) the aggregate royalties obtained for the various features of a product exceed the value of the product itself." 6

\section{SDO IP Policies}

In order to mitigate the threats of patent hold-up and royalty stacking, many SDOs have adopted internal policies that are binding on their participants. These policies fall into two general categories: disclosure policies and licensing policies. Disclosure policies require SDO participants to disclose SEPs that they hold, generally prior to the approval of a relevant standard. These

${ }^{4}$ Microsoft v. Motorola, 795 F.3d at 1031 (citing Ericsson, Inc. v. D-Link Sys., Inc., 773 F.3d 1201, 1209 (Fed. Cir. 2014)).

${ }^{5}$ Ericsson v. D-Link, 773 F.3d at 1209.

${ }^{6}$ Microsoft v. Motorola, 795 F.3d at 1031. 
disclosures are often made available to the public via the Internet. Early disclosure of SEPs enables standards developers to decide whether or not to approve a design that is covered by these SEPS, to choose an alternative, non-infringing technology, to modify a draft standard before it is approved to eliminate the infringing feature, or to seek licenses to the patented technology.

Licensing policies, on the other hand, require SEP holders to grant manufacturers of standardized products licenses to use their SEPs on terms that are either royalty-free (RF) or "fair, reasonable and nondiscriminatory" (FRAND). These commitments are intended to assure product manufacturers that they will be able to obtain all SEP licenses necessary to manufacture a standardized product. FRAND or RF licensing commitments are required of all SDOs accredited by the American National Standards Institute (ANSI) and are also utilized widely among other SDOs around the world.

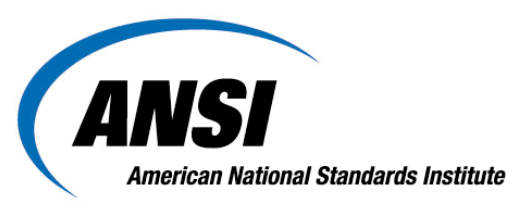

Essential Requirements, Section 3.1.1.b

A holder of standards-essential patents must offer all implementers of the standard "reasonable terms and conditions that are demonstrably free of any unfair discrimination"

Before diving into the issues surrounding FRAND royalty rates, it is important to make two ancillary points. First, a FRAND commitment, such as the one illustrated above, is not itself a license. It is a promise to enter into a license. As such, it is a binding obligation, but it is not itself a conveyance of rights to the licensee. ${ }^{7}$ Second, most SDO licensing commitments require that all terms of a SEP license be fair and reasonable, not only the royalty provisions. For obvious reasons, royalty rates have gotten most of the attention in recent FRAND litigation (see below), but there are other significant terms in every FRAND license agreement that should not be ignored. In most cases, these terms (scope, duration, disclaimers, indemnity, etc.) are similar or identical to comparable terms in other patent license agreements, which are discussed elsewhere in this volume. In many respects, FRAND patent licenses share similarities with open source code software licenses (Chapter 19), inasmuch as they are non-exclusive and carry few or no warranties or indemnities. Some have also required the licensee to grant a license in improvements, or its own

${ }^{7}$ This point is discussed in Jorge L. Contreras, A Market Reliance Theory for FRAND Commitments and Other Patent Pledges, 2015 Utah L. Rev. 479, 497-98 (2015). 
patents, back to the licensor, sometimes at no charge. A sample FRAND license agreement is included in the Supplemental Materials at Appendix 20.1.

\section{The Challenge of Defining FRAND Royalty Rates}

Despite the appeal of FRAND licensing commitments, a consistent, practical, and readily enforceable definition of the level of a FRAND royalty for a given patent/standard, or a methodology for calculating FRAND royalties more generally, has proven difficult to achieve. Virtually no SDO defines precisely what this phrase means, and many SDOs affirmatively disclaim any role in establishing, interpreting, or adjudicating the reasonableness of FRAND royalties. As explained in the common patent policy adopted by ISO, ITU and IEC, "The detailed arrangements arising from patents (licensing, royalties, etc.) are left to the parties concerned, as these arrangements might differ from case to case." Some SDOs even go so far as to prohibit discussions of royalties and other licensing terms at SDO meetings, making the development of a consensus view on the precise meaning of FRAND difficult. This lack of clarity has contributed to litigation over FRAND commitments.

These disputes have arisen when a SEP holder and a product manufacturer cannot agree on the terms of a license and there is disagreement whether the patent holder's proposed royalty is "reasonable." However, FRAND disputes can also involve the reasonableness of non-royalty terms, such as requirements that the vendor license-back its own patents to the patent holder ("reciprocity") or that the license be "suspended" if the manufacturer threatens the patent holder with litigation ("defensive suspension"). When parties cannot agree on license terms, no license is granted and any product that conforms to a standard may infringe the patent holder's SEPs. The parties are thus left in a difficult and ambiguous situation, which has led to a vigorous debate within industry, government, and academia regarding the scope and contour of FRAND obligations. Some of the specific issues arising in these disputes are discussed in the following sections.

\section{NOTES AND QUESTIONS}

1. Essentiality. The SDO disclosure and licensing policies described above relate primarily to patents that are "essential" to the SDO's standards. This qualifier is important, as SDOs would likely be overstepping their bounds if they sought to require patent holders to disclose or license patents that did not directly impact a manufacturer's ability to implement the SDO's standards. But what, exactly, does "essential" mean? This question has been heavily debated, and SDOs generally take one of three approaches. Some speak in terms of patents that are "technically" essential to a standard, some speak in terms of those that are "commercially" essential, and some do not specify which of these approaches they prefer. The following excerpt highlights some of the issues that can arise with respect to this critical definition:

One major divide among SDO patent policies is whether they define an "essential" patent claim as covering a technology that must, as a technical or engineering matter, be included in a product implementing a standard (technical essentiality) or whether that patented technology, though not strictly required as a technical matter, is the only commercially feasible way that the standard can be implemented (i.e., 
considering factors such as manufacturing cost, efficiency, reliability, manufacturability, etc.) (commercial essentiality).

For example, suppose that a municipal electrical standard specifies a range of tolerances (pressure, temperature, corrosion resistance, puncture resistance, etc.) for wiring conduits. Such conduits are typically made from aluminum, though other materials could also be used to make such conduits. Thus, a patent covering the use of aluminum conduits for wiring would not be technically essential to the standard, as one could use various other materials. But suppose that the only alternative material that met the other tolerance requirements of the specification were gold. Aluminum conduit costs an average of $\$ 0.15$ per meter, while gold conduit, if such a thing were ever made, would cost $\$ 2,000.00$ per meter. Under this scenario, a patent covering aluminum conduit might no longer be considered technically essential to the standard, as gold, technically speaking, could also be used to make compliant conduits. Nevertheless, given these two alternatives, there is no commercially feasible alternative to aluminum. Thus, when the only technical substitute for aluminum conduit is significantly more costly, a patent covering the use of aluminum conduit would likely be commercially essential to the standard.

But what if, in addition to aluminum and gold, polyvinyl chloride (PVC) is also a suitable material for conduit which meets all the requirements of the specification. PVC costs $\$ 0.45$ per meter: three times more than aluminum, but far less than gold. Is PVC, at three times the cost of aluminum, a commercially feasible substitute for aluminum? If so, is an aluminum conduit patent still commercially essential to the implementation of the conduit standard? What if the cost of PVC conduit dropped to $\$ 0.25$ per meter? Or to $\$ 0.16$ ? Just how different must the qualities and pricing of a substitute technology (PVC) be before another technology (aluminum) is no longer considered commercially essential to the standard?

This question of degree must be factored into the analysis by SDOs deciding how to define essentiality. While technical essentiality may seem rather unforgiving and unfairly exclude some patents from the reach of the SDO's policy (e.g., a patent on aluminum conduit, when gold exists as a technically-, though not commerciallyfeasible, alternative), the virtually limitless gradations of pricing, quality and availability that factor into commercial manufacturing decisions could make determinations as to commercial essentiality hopelessly fraught. ${ }^{8}$

What advantages and drawbacks do each of the approaches outlined above have for SDO participants, the SDO itself, and the standards that are developed? Given these considerations, how would you define "essentiality" in a new SDO's patent policy?

2. De Facto Standards. The standards discussed in this chapter are generally known as "voluntary consensus standards" and are developed by groups of competitors within SDOs. However, not all standards are created in this way. Several important standards that are widely deployed in the market were developed by a single firm and became so broadly used that they have

\footnotetext{
${ }^{8}$ Jorge L. Contreras, Essentiality and Standards Essential Patents in Cambridge Handbook Of Technical Standardization Law: Competition, Antitrust, and Patents, 209, 217-18 (Jorge L. Contreras, ed., Cambridge Univ. Press: 2017).
} 
come to be considered standards (generally known as "de facto" standards). An example is Adobe's Portable Document Format (PDF). Though Adobe originally developed PDF as a proprietary document format, PDF has become so widespread that Adobe has made available the tools necessary to read and convert PDF documents to the industry generally. Yet because Adobe developed PDF on its own and without the involvement of an SDO, the standard carries no FRAND or other licensing commitments to third parties. Should firms like Adobe be required to license patents covering de facto standards to others, including their competitors? Some commentators have argued that they should, while others worry that doing so could be problematic. ${ }^{9}$ What do you think?

3. Patent Pools. As discussed in Chapter 27, patent pools are created when the holders of patents wish to license their patents collectively, at uniform rates via a single point of contact. Over the years, patent pools have formed to facilitate the licensing of patents covering several important standards including Advanced Audio Coding (AAC), Digital Video Broadcast (DVB), Compact Disc (CD) and Digital Video Disc (DVD). The Department of Justice has reviewed several of these pooling arrangements and has generally concluded that they are likely to have significant procompetitive effects. ${ }^{10}$

Yet most SDO-developed standards are not associated with patent pools, and the licensing of SEPs is conducted on a bilateral basis between individual SEP holders and product manufacturers. One recent study found that of more than 250 standards implemented in a new laptop computer, only $3 \%$ of them were subject to SEP licensing under a patent pool, while $75 \%$ were covered by FRAND licensing policies and $22 \%$ were subject to royalty-free licensing. ${ }^{11}$

One of the principal reasons patent pools are used infrequently in the context of voluntary consensus standards relates to "essentiality", discussed in Note 1 above.

$[\mathrm{P}]$ atent pools must ensure, with a high degree of certainty, that all patents placed in the pool are essential. This requirement flows from the risk that a patent pool may stifle competition if it contains patents covering substitute technologies. Under this theory, including substitute technologies in the pool could effectively fix prices on competing technologies. For this reason, the parties forming patent pools typically engage in a lengthy and expensive process (usually through external counsel engaged for the purpose) of vetting each patent that is proposed to be included in the pool and ensuring its essentiality.

\footnotetext{
${ }^{9}$ Compare Robert P. Merges \& Jeffrey M. Kuhn, An Estoppel Doctrine for Patented Standards, 97 Calif. L. Rev. 1, 4 (2009) (arguing that Adobe and other holders of de facto standards should be required to make their patents broadly available under the doctrine of equitable estoppel) with Contreras, Market Reliance, supra note 7, at 522-23 (significant mischief could ensue from requiring involuntary licensing of proprietary technologies).

${ }^{10}$ U.S. Dep't Justice \& Fed. Trade Comm'n, Antitrust Enforcement And Intellectual Property Rights: Promoting Innovation and Competition 71 (2007).

${ }^{11}$ Brad Biddle, Andrew White \& Sean Woods, How Many Standards in a Laptop? (And Other Empirical Questions), Int'l Telecomm. Union Sec. Telecomm. Standardization Kaleidoscope Acad. Conf. Proc. 123 (2010).
} 
Such a vetting process would typically be cost-prohibitive in the context of SDObased standards. Some SDOs produce hundreds or thousands of standards in a wide range of product areas. Many SDO standards are never widely adopted or have limited application, so much of an up-front investment of resources to determine essentiality would be wasted. In contrast, relatively little up-front investment is required to identify SEPs in SDOs: patents are voluntarily declared essential by patent holders and essentiality is not tested unless and until litigation ensues. While this structure relies on litigation to resolve questions regarding patent essentiality, its significant up-front cost savings makes it far more desirable in the SDO context. ${ }^{12}$

Given these differences, do you see any way to increase the efficiency of SEP licensing for SDOs?
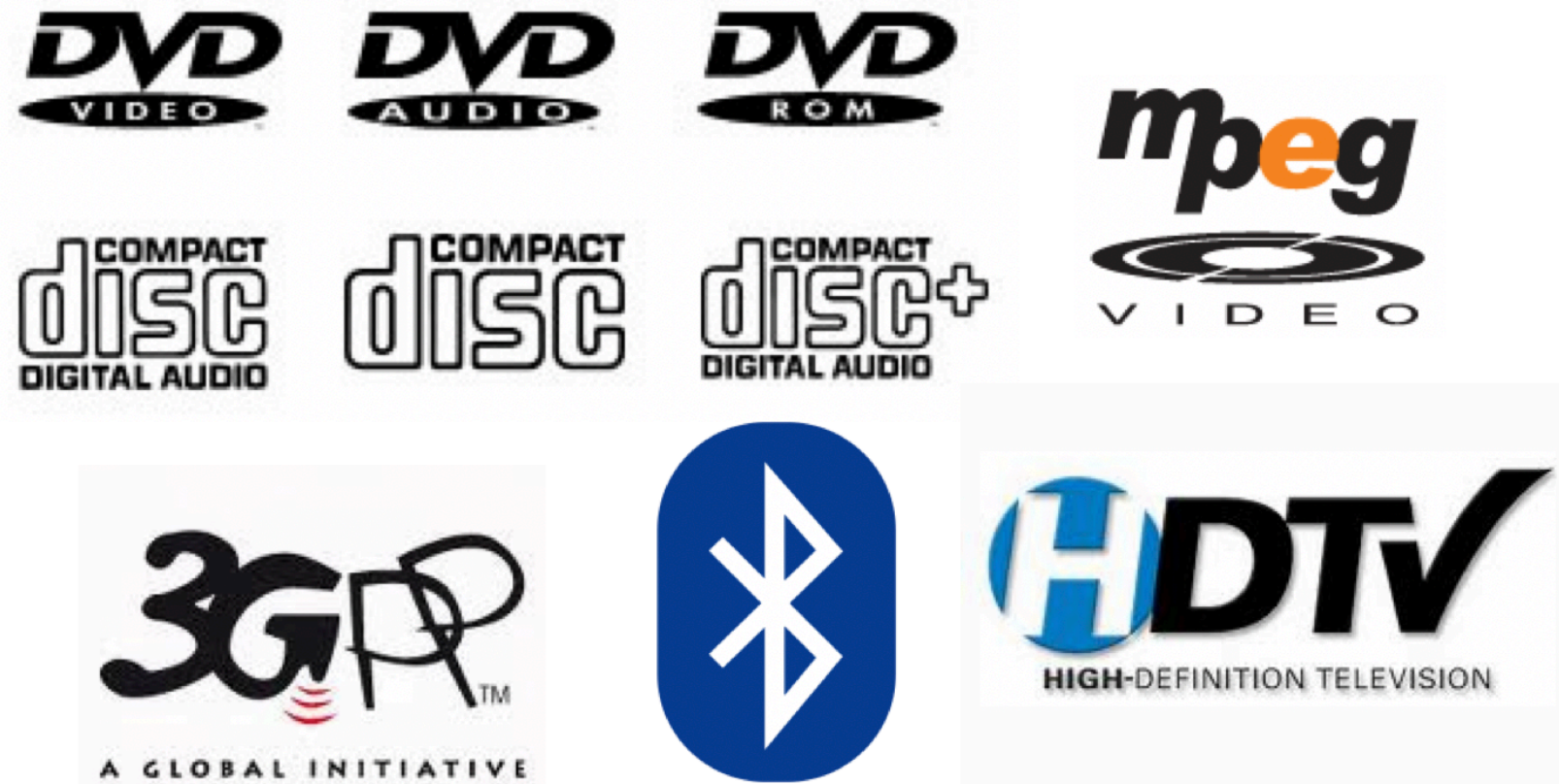

A CLOBAL INITIATIVE

SEPs covering many important standards are licensed through patent pools

\section{B. Patent Disclosure Policies}

As discussed above, many SDOs require that their participants disclose patents that are likely to be "essential" to standards under development by the SDO. However, the specific conditions under which such disclosures must be made are sometimes hazy. The cases in this section address what happens when an SDO participant allegedly fails to comply with its obligation to disclose SEPs to an SDO.

12 Jorge L. Contreras, Fixing FRAND: A Pseudo-Pool Approach to Standards-Based Patent Licensing, 79 Antitrust L.J. 47, 76-77 (2013). 


\section{QUALCOMM INC. V. BROADCOM CORP.}

548 F.3d 1004 (Fed. Cir. 2008)

PROST, CIRCUIT JUDGE.

\section{BACKGROUND}

This case presents the question of whether Qualcomm waived its right to assert its patents by failing to disclose them to the JVT SSO. The asserted patents relate to video compression technology. The '104 Patent issued in 1995 and is entitled, "Adaptive Block Size Image Compression Method and System." The '767 Patent issued in 1996 and is entitled, "Interframe Video Encoding and Decoding System." Qualcomm is the assignee of the '104 and '767 Patents.

In late 2001, the JVT was established as a joint project by two parent SSOs: (1) the Video Coding Experts Group ("VCEG") of the International Telecommunication Union Telecommunication Standardization Sector ("ITU-T"); and (2) the Moving Picture Experts Group ("MPEG") of the International Organization for Standardization ("ISO") and the International Electrotechnical Commission ("IEC"). The JVT was created to develop a single "technically aligned, fully interoperable" industry standard for video compression technology. The standard developed by the JVT was later named the H.264 standard. In May 2003, the ITU-T and ISO/IEC adopted and published the official H.264 standard.

Plaintiff Qualcomm is a member of the American National Standards Institute ("ANSI"), which is the United States representative member body in the ISO/IEC, and was an active duespaying member for many years prior to 2001. It is also a member of the ITU-T and a participant in the JVT. Qualcomm did not disclose the '104 and ' 767 Patents to the JVT prior to release of the H.264 standard in May 2003.

On October 14, 2005, Qualcomm filed the present lawsuit against Broadcom in the United States District Court for the Southern District of California, claiming that Broadcom infringed the ' 104 and ' 767 Patents by making products compliant with the H.264 video compression standard. A jury trial was held from January 9, 2007, to January 26, 2007. The jury returned a unanimous verdict as to non-infringement and validity, finding that (1) Broadcom does not infringe the '104 and '767 Patents; and (2) the '104 and '767 Patents were not shown to be invalid. The jury also returned a unanimous advisory verdict as to the equitable issues, finding by clear and convincing evidence that (1) the '104 Patent is unenforceable due to inequitable conduct; and (2) the '104 and '767 Patents are unenforceable due to waiver.

On March 21, 2007, the district court entered an order (1) finding in favor of Qualcomm and against Broadcom on Broadcom's counterclaim of inequitable conduct as to the '104 Patent; (2) finding in favor of Broadcom and against Qualcomm on Broadcom's affirmative defense of waiver as to the '104 and '767 Patents; and (3) setting a hearing on an Order to Show Cause as to the appropriate remedy for Qualcomm's waiver. The district court's conclusion that Qualcomm waived its rights to assert the '104 and '767 Patents was based on Qualcomm's conduct before the JVT.

Throughout discovery, motions practice, trial, and even post-trial, Qualcomm adamantly maintained that it did not participate in the JVT during development of the H.264 standard. Despite 
numerous requests for production and interrogatories requesting documents relating to Qualcomm's JVT participation prior to adoption of the H.264 standard, Qualcomm repeatedly represented to the court that it had no such documents or emails. On January 24, 2007, however, one of the last days of trial, a Qualcomm witness testified that she had emails that Qualcomm previously claimed did not exist. Later that day, Qualcomm produced twenty-one emails belonging to that witness. As the district court later discovered, these emails were just the "tip of the iceberg," as over two hundred thousand more pages of emails and electronic documents were produced posttrial. The district court later determined that these documents and emails "indisputably demonstrate that Qualcomm participated in the JVT from as early as January 2002, that Qualcomm witnesses . . . and other engineers were all aware of and a part of this participation, and that Qualcomm knowingly attempted in trial to continue the concealment of evidence."

On August 6, 2007, after a hearing on the Order to Show Cause, the district court entered an Order on Remedy for Finding of Waiver, ordering the '104 and '767 Patents (and their continuations, continuations-in-part, divisions, reissues, and any other derivatives thereof) unenforceable against the world.

This appeal followed.

\section{DISCUSSION}

By failing to disclose relevant intellectual property rights ("IPR") to an SSO prior to the adoption of a standard, a "patent holder is in a position to 'hold up' industry participants from implementing the standard. Industry participants who have invested significant resources developing products and technologies that conform to the standard will find it prohibitively expensive to abandon their investment and switch to another standard." In order to avoid "patent hold-up," many SSOs require participants to disclose and/or give up IPR covering a standard.

In Rambus Inc. v. Infineon Technologies $A G$, this court considered the question of whether the plaintiff, Rambus, had a duty to disclose information about patents or patent applications to the Joint Electron Device Engineering Council ("JEDEC"), which is an SSO associated with the Electronic Industries Alliance ("EIA"). 318 F.3d 1081, 1096 (Fed. Cir. 2003). It stated that, "[b]efore determining whether Rambus withheld information about patents or applications in the face of a duty to disclose, this court first must ascertain what duty Rambus owed JEDEC." In determining what duty, if any, Rambus owed JEDEC, our court considered both the language of the written EIA/JEDEC IPR policy and the members' treatment of said language. It determined that the written policy did not impose a direct duty on members expressly requiring disclosure of IPR information. "Nevertheless, because JEDEC members treated the language of [the policy] as imposing a disclosure duty, this court likewise treat[ed] this language as imposing a disclosure duty."

After considering evidence regarding the JEDEC members' understanding of the JEDEC policy, this court determined that "Rambus's duty to disclose extended only to claims in patents or applications that reasonably might be necessary to practice the standard." Applying that rationale to the claims at issue and the evidence in the case, it stated that " $[\mathrm{t}]$ he record shows that Rambus's claimed technology did not fall within the JEDEC disclosure duty." Accordingly, this court concluded that "substantial evidence does not support the jury's verdict that Rambus breached its duties under the EIA/JEDEC policy." 


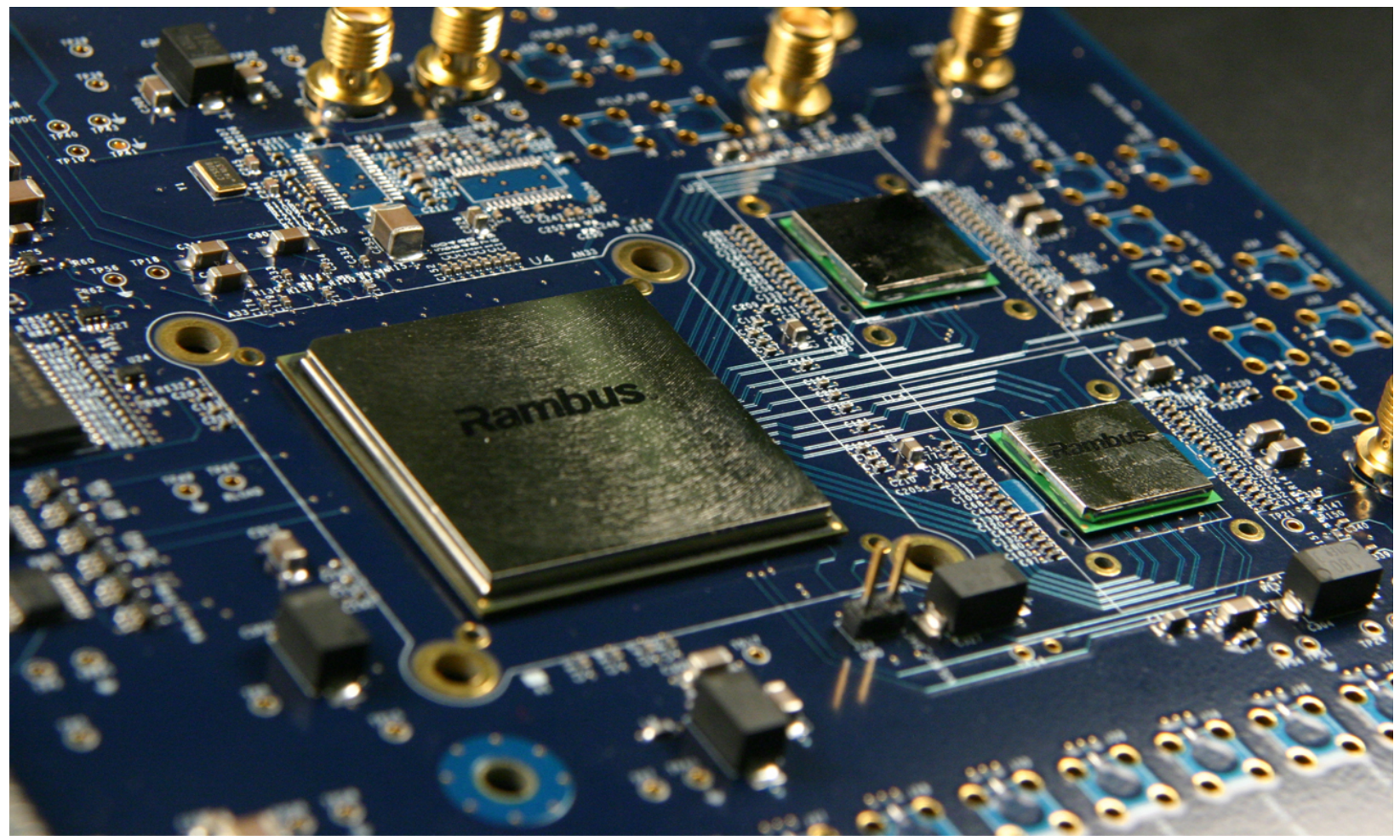

Chip designer Rambus was at the center of some of the largest standards-related patent disputes of the 2000s.

\section{A. Existence of Disclosure Duty}

Determining whether Qualcomm had a duty to disclose the '104 and '767 Patents to the JVT involves two questions. First, we must determine whether the written JVT IPR policies impose any disclosure obligations on participants (apart from the submission of technical proposals). Second, to the extent the written JVT IPR policies are ambiguous, we must determine whether the JVT participants understood the policies as imposing such obligations.

The district court first considered the written JVT IPR policies. Specifically, the district court considered the JVT ToR, which encompass patent and copyright IPR. As the district court noted, the IPR disclosure provisions of the JVT IPR policies apply to Qualcomm, as a member of the ITU-T and participant in the JVT.

Section 3 of the JVT ToR is entitled "IPR Policy \& Guidelines." Subsection 3.2, entitled "Collection of IPR information during the standardization process," reads:

According to the ITU-T and ISO/IEC IPR policy, members/experts are encouraged to disclose as soon as possible IPR information (of their own or anyone else's) associated with any standardization proposal (of their own or anyone else's). Such information should be provided on a best effort basis. ... 
As the district court observed, it is clear from a review of the JVT IPR policies that identification of IPR by JVT participants is critical to the development of an effective industry standard.

On appeal, the threshold dispute between the parties is whether the written JVT IPR policies impose any disclosure duty on participants apart from the submission of technical proposals. Qualcomm argues that the written JVT IPR policies require disclosure only when a technical proposal is made, and that disclosure is merely encouraged from participants not submitting technical proposals. Broadcom, however, argues that the written policies of both the JVT and its parent organizations impose disclosure obligations on participants (apart from the submission of technical proposals). Additionally, Broadcom submits that, to the extent there is any ambiguity in the written policies, the understanding of the JVT participants controls.

Pointing to subsection 3.2, Qualcomm argues that the express language of the written JVT policies only requires disclosure when a technical proposal is made, and that disclosure is merely "encouraged" from participants not making technical proposals. Thus, Qualcomm argues that the district court erred in holding that Qualcomm waived patent rights by breaching an "unwritten" JVT disclosure duty. In addition to the language of subsection 3.2, Qualcomm points to the JVT patent disclosure form, which states: "JVT requires that all technical contributions be accompanied with this form. Anyone with knowledge of any patent affecting the use of JVT work, of their own or any other entity ('third parties'), is strongly encouraged to submit this form as well."

As Broadcom notes, however, subsection 3.2 expressly incorporates a "best effort[s]" standard. When asked at oral argument whether there is any evidence in the record that Qualcomm made any efforts, let alone best efforts, to disclose IPR information associated with any standardization proposal, Qualcomm responded, 'No, we didn't because we did not view that as imposing a duty on us." On rebuttal, Qualcomm clarified this response by arguing that the use of best efforts is merely "encouraged," not required.

We disagree with Qualcomm's reading of subsection 3.2. While Qualcomm places much emphasis on the use of the word "encouraged" in subsection 3.2, we agree with Broadcom that, when considered in light of the relevant context, this language applies to the timing of the disclosure (i.e., encouraged to disclose as soon as possible), not the disclosure duty itself. Thus, while the language of the JVT IPR policies may not expressly require disclosure by all participants in all circumstances (e.g., if relevant IPR is not disclosed despite the use of best efforts), it at least incorporates a best efforts standard (even apart from the submission of technical proposals). By Qualcomm's own admission, it did not present evidence of any efforts, much less best efforts, to disclose patents associated with the standardization proposal (of their own or anyone else's) to the JVT prior to the release of the H.264 standard.

In sum, we conclude that Qualcomm, as a participant in the JVT prior to the release of the H.264 standard, did have IPR disclosure obligations, as discussed above, under the written policies of both the JVT and its parent organizations.

\section{JVT Participants' Understanding of the JVT IPR Policies}

Even if we were to read the written IPR policies as not unambiguously requiring by themselves the aforementioned disclosure obligations, our conclusion as to the disclosure obligations of JVT participants would nonetheless be the same. That is because the language of the JVT IPR policies coupled with the district court's unassailable findings and conclusions as to the JVT participants' 
understanding of the policies further establishes that the policies imposed disclosure duties on participants (apart from the submission of technical proposals). As previously discussed, even though the Rambus court determined that there was not an express disclosure duty in the JEDEC patent policy in that case, it treated the policy as imposing a disclosure duty because the members treated it as imposing a disclosure duty.

In the present case, while the district court concluded that there was no express disclosure requirement in the written policies apart from the submission of technical proposals, it found "clear and convincing evidence that JVT participants treated the JVT IPR Policies as imposing a duty to disclose," and "that Qualcomm was aware of this treatment as early as August 2002," prior to the release of the H.264 standard in May 2003. Specifically, the district court noted that, "like Rambus, in addition to the written guidelines, JVT participants also learned of the patent disclosure policy from attendance of JVT meetings."

The district court considered witness testimony, including testimony from Qualcomm employees, indicating that it was the practice of the chairman of the JVT, Gary Sullivan, to discuss the JVT IPR policies at every meeting. The district court also considered testimony indicating that JVT participants sometimes submitted disclosures without an accompanying technical proposal.

Qualcomm attempts to distinguish Rambus by arguing that the JEDEC patent policy in Rambus was silent as to whether members had a disclosure duty, while the written JVT IPR policies are "unambiguous," and "expressly specify disclosure duties only in conjunction with a submission". Thus, Qualcomm argues that the district court erred by inferring a disclosure duty that is "directly contrary to the written JVT policy." As previously discussed, however, we disagree with Qualcomm's interpretation of the written JVT IPR policies in the present case. Moreover, even if we were to read the written IPR policies as not unambiguously requiring by themselves the aforementioned disclosure obligations, the disclosure duty found by the district court based on the understanding of the JVT participants is certainly not "directly contrary to the written JVT policy."

\section{B. Scope of Disclosure Duty}

Having concluded that Qualcomm, as a participant in the JVT prior to release of the H.264 standard, had a duty to disclose patents, we turn to the question of the scope of the disclosure duty. In Rambus, although the JEDEC IPR policy did not use the language "related to," the parties consistently agreed that the policy required disclosure of patents "related to" the standardization work of the committee. The parties disagreed, however, in their interpretation of "related to". The court considered evidence regarding the JEDEC members' understanding of the JEDEC policy, and concluded that "Rambus's duty to disclose extended only to claims in patents or applications that reasonably might be necessary to practice the standard". The court reasoned that, "[t]o hold otherwise would contradict the record evidence and render the JEDEC disclosure duty unbounded. Under such an amorphous duty, any patent or application having a vague relationship to the standard would have to be disclosed". The court noted, "[j] ust as lack of compliance with a welldefined patent policy would chill participation in open standard-setting bodies, after-the-fact morphing of a vague, loosely defined policy to capture actions not within the actual scope of that policy likewise would chill participation in open standard-setting bodies."

In the present case, the district court noted that the JVT IPR policies refer to IPR information "associated with" any standardization proposal or "affecting the use" of JVT work. Applying the 
reasoning of Rambus, the district court concluded that this language requires only that JVT participants disclose patents that "reasonably might be necessary" to practice the H.264 standard. To hold otherwise, the district court explained, "would render the JVT disclosure duty inappropriately 'unbounded,' 'amorphous,' and 'vague.",

On appeal, Qualcomm argues that we should reject the district court's formulation of the "reasonably might be necessary" standard. Qualcomm characterizes the "reasonably might be necessary" formulation from Rambus as follows: "it must be reasonably clear at the time that the patent or application would actually be necessary to practice the standard." Thus, according to Qualcomm, when the Rambus court explained the standard in terms of whether the patent or application "reasonably might be necessary" to practice the standard, the court really meant that the patent or application must "actually be necessary" to practice the standard. Qualcomm submits that "[i]t is nonsensical to conceive that an SSO would require disclosure to design a standard around a patent when the standard does not read on the patent in the first place."

We disagree with Qualcomm's characterization of the standard applied in Rambus. The plain language used by the Rambus court ("reasonably might be necessary") contradicts Qualcomm's claim that the Rambus formulation requires that a patent must "actually be necessary" in order to trigger a disclosure duty. The Rambus court explained the "reasonably might be necessary" standard by stating that "the disclosure duty operates when a reasonable competitor would not expect to practice the standard without a license under the undisclosed claims."

It further clarified that the "reasonably might be necessary" standard is an objective standard, which "does not depend on a member's subjective belief that its patents do or do not read on the proposed standard." Likewise, in the present case, we agree with the district court that the language requires JVT participants to disclose patents that "reasonably might be necessary" to practice the H.264 standard. This is an objective standard, which applies when a reasonable competitor would not expect to practice the H.264 standard without a license under the undisclosed claims. This formulation does not require that the patents ultimately must "actually be necessary" to practice the H.264 standard.

\section{Breach of Disclosure Duty}

Having concluded that the proper scope of the disclosure duty requires JVT participants to disclose patents that "reasonably might be necessary" to practice the H.264 standard, we next address the question of whether Qualcomm breached this disclosure duty. It is undisputed that Qualcomm did not disclose the '104 and '767 Patents to the JVT prior to the release of the H.264 standard. Thus, Qualcomm breached its disclosure duty if, as the district court found by clear and convincing evidence, the '104 and ' 767 Patents "reasonably might be necessary" to practice the H.264 standard.

As previously mentioned, the district court found clear and convincing evidence that the '104 and '767 Patents "reasonably might be necessary" to practice the H.264 standard. In reaching this conclusion, the district court relied on the testimony from several Qualcomm witnesses. For example, the district court relied on testimony from Qualcomm's H.264 expert, who testified at trial that "the claims of the ['104] patent map onto the H.264 standard, so that devices or systems that practice H.264 actually practice claims of the "104 patent." Additionally, inter alia, the district 
court relied on an email from a Qualcomm employee discussing the coverage of the '767 Patent, and describing it as a "core patent relevant to H.264."

Qualcomm argues that the finding of non-infringement here refutes any finding that it breached a disclosure duty. Broadcom responds, however, that it is inconsistent for Qualcomm to now argue that the asserted patents do not meet the "reasonably might be necessary" standard, when Qualcomm accused Broadcom's products of infringement in this case solely because they practiced the H.264 standard. Broadcom also points to testimony of Qualcomm's own JVT participants in support of its claim that JVT participants considered that the asserted patents "reasonably might be necessary" to practice the H.264 standard.

On appeal, Qualcomm does not present any arguments comparing the asserted claims to the H.264 standard in an attempt to show that they do not meet the "reasonably might be necessary" formulation. Indeed, Broadcom argues that if Qualcomm truly believes that the asserted patents do not meet the "reasonably might be necessary" standard, then it necessarily lacked a Rule 11 basis to bring this litigation in the first place.

We are not persuaded by Qualcomm's arguments on this point, and are unable to reconcile its ex post argument that the asserted patents do not meet the "reasonably might be necessary" standard with its ex ante arguments regarding infringement. Based on the foregoing, we conclude that the district court did not err in finding clear and convincing evidence that the '104 and '767 Patents fell within the "reasonably might be necessary" standard. Thus, the district court properly determined that Qualcomm breached its disclosure duty by failing to disclose the '104 and '767 Patents to the JVT prior to the release of the H.264 standard in May 2003.

Accordingly, we turn to the question of whether it was within the district court's equitable authority to enter an unenforceability remedy in this case.

\section{Equitable Remedies}

The district court analyzed the consequence of Qualcomm's failure to disclose the '104 and '767 Patents under the framework of waiver as a consequence of silence in the face of a duty to speak. The parties disagree on whether waiver was the appropriate equitable framework, and whether the scope of the unenforceability remedy was within the district court's equitable authority.

\section{Waiver}

First, we address the question of whether waiver was the appropriate equitable doctrine to apply in this case. Qualcomm argues that the district court's findings do not constitute waiver as a matter of law. It argues that "true waiver" requires a voluntary or intentional relinquishment of a known right.

Specifically, Qualcomm claims that the district court's findings in this case run directly contrary to any claim that Qualcomm intended to voluntarily waive its patent rights. On this point, we agree with Qualcomm. The following finding by the district court certainly suggests that Qualcomm did not intend to waive its patent rights:

The Court finds by clear and convincing evidence that Qualcomm intentionally organized a plan of action to shield the '104 and '767 patents from consideration by the JVT with the anticipation that (1) the resulting H.264 standard would 
infringe those patents and (2) Qualcomm would then have an opportunity to be an indispensable licensor to anyone in the world seeking to produce an H.264compliant product.

Therefore, rather than establishing that Qualcomm intentionally relinquished its rights, the district court's findings demonstrate that Qualcomm intentionally organized a plan to shield its patents from consideration by the JVT, intending to later obtain royalties from H.264-compliant products. Thus, in these circumstances, it appears that "true waiver" is not the appropriate framework.

As Broadcom notes, however, the district court's formulation of the law of waiver was not limited to "true waiver," but also addressed "implied waiver." The district court's advisory jury instruction stated:

In order to prove waiver, Broadcom must show by clear and convincing evidence either that Qualcomm, with full knowledge of the material facts, intentionally relinquished its rights to enforce the 104 and 767 patents or that its conduct was so inconsistent with an intent to enforce its rights as to induce a reasonable belief that such right has been relinquished.

Broadcom submits that "[t]he second element of that instruction correctly states the longestablished doctrine of implied waiver."

Qualcomm responds that "[e]ven if a duty to disclose had been breached, this breach is best explained as negligence, oversight, or thoughtlessness, which does not create a waiver." In the present case, however, the district court found clear and convincing evidence that Qualcomm knew that the asserted patents "reasonably might be necessary" to practice that H.264 standard, and that it intentionally did not disclose them to the JVT. These findings demonstrate much more than "negligence, oversight, or thoughtlessness."

Qualcomm also argues that any "nondisclosure did not cause any harm to Broadcom or any other entity." Qualcomm submits that there is no harm because (1) the jury's non-infringement verdict conclusively establishes that the asserted patents are not needed to produce H.264compliant products, and (2) even if the asserted patents were needed to practice the H.264 standard, Qualcomm would be willing to license them. We disagree. Even if Qualcomm agreed not to pursue an injunction in this case, injunctions are not the only type of harm. Forcing a party to accept a license and pay whatever fee the licensor demands, or to undergo the uncertainty and cost of litigation (which in this case was substantial), are significant burdens.

Qualcomm further argues that "[ $\mathrm{t}]$ he district court never found detrimental reliance by Broadcom because of its misconception that such reliance is not an element of a defense premised on conduct that allegedly is objectively misleading to a reasonable person." In essence, it appears that Qualcomm wants to benefit from its intentional nondisclosure of the asserted patents by arguing that Broadcom cannot succeed on an implied waiver defense without specific findings as to detrimental reliance by Broadcom.

We disagree with Qualcomm's contention that the district court's findings in this case were insufficient to support the application of an implied waiver defense. The district court found that JVT participants understood the JVT IPR policies as imposing a disclosure duty, that Qualcomm participated in the JVT prior to release of the H.264 standard, and that Qualcomm was silent in the face of its disclosure duty. Indeed, the district court stated that "participants in the JVT project 
shared the aims and policies of the JVT and considered themselves obligated to identify IPR owned or known by them, whether or not they made technical proposals for study." As the district court noted, "Broadcom, ignorant of the existence of the '104 and '767 patents, designed and is in the process of manufacturing numerous H.264-compliant products." In light of the record in this case in its entirety, it would be improper to allow Qualcomm to rely on the effect of its misconduct to shield it from the application of the equitable defense of implied waiver.

In sum, we agree with the district court that, "[a] duty to speak can arise from a group relationship in which the working policy of disclosure of related intellectual property rights ('IPR') is treated by the group as a whole as imposing an obligation to disclose information in order to support and advance the purposes of the group." Not only did the district court find that Qualcomm was silent in the face of a disclosure duty in the SSO context, it also found clear and convincing evidence that Qualcomm had knowledge, prior to the adoption of the H.264 standard in May 2003, that the JVT participants understood the policies as imposing a disclosure duty, that the asserted patents "reasonably might be necessary" to practice the H.264 standard, and that Qualcomm intentionally organized a plan to shield said patents from consideration by the JVT, planning to demand license fees from those seeking to produce H.264-compliant products. Then, after participating in the JVT and shielding the asserted patents from consideration during development of the H.264 standard, Qualcomm filed a patent infringement lawsuit against Broadcom, alleging infringement primarily, if not solely, based on Broadcom's H.264 compliance. In these circumstances, we conclude that it was within the district court's authority, sitting as a court of equity, to determine that Qualcomm's misconduct falls within the doctrine of waiver.

\section{Unenforceability Remedy}

On August 6, 2007, after a hearing on the Order to Show Cause, the district court entered an Order on Remedy for Finding of Waiver, ordering the '104 and '767 Patents (and their continuations, continuations-in-part, divisions, reissues, and any other derivatives thereof) unenforceable against the world. In reaching this conclusion, the district court rejected Qualcomm's argument that Broadcom may not have any remedies beyond itself, because it raised waiver as an affirmative defense rather than as a counterclaim or cross-claim. The district court noted that this court has upheld the unenforceability of a patent to the world due to inequitable conduct even when pled as an affirmative defense.

Qualcomm argues that the remedy of unenforceability entered on Broadcom's defense of waiver is contrary to law. It submits that once the jury returned a non-infringement verdict the district court lacked any legal basis to consider the affirmative defense of waiver. It appears to base this argument largely on the fact that Broadcom pled waiver only as an affirmative defense, as opposed to a counterclaim. Thus, Qualcomm argues that, because waiver was pled as an affirmative defense, it cannot result in a judgment of unenforceability. We disagree. It was entirely appropriate for the district court to address the defense of waiver after the jury returned a noninfringement verdict. As the district court noted, this court has upheld judgments of unenforceability based on inequitable conduct even where pled as an affirmative defense. We see no reason why an affirmative defense of waiver cannot similarly result in a judgment of unenforceability.

Broadcom also submits that "[t]he district court, sitting in equity, had the authority to grant relief as a result of Qualcomm's conduct." By analogy, it claims that successful assertion of the defenses of inequitable conduct, equitable estoppel, and patent misuse has resulted in 
unenforceability judgments. In response to Broadcom's analogy to inequitable conduct, Qualcomm argues "the rationale for a remedy of unenforceability for inequitable conduct before the PTO--that such conduct taints the property right ab initio--is simply not present for waiver based on post-PTO conduct before a private SSO." In response to the patent misuse analogy, Qualcomm states that "[w]hen patent misuse is proven, a court may temporarily suspend the owner's ability to enforce the patent while the improper practice and its effects remain ongoing."

In addition to the analogy to inequitable conduct, we find the remedy of unenforceability based on post-issuance patent misuse instructive in this case. As Qualcomm notes, the successful assertion of patent misuse may render a patent unenforceable until the misconduct can be purged; it does not render the patent unenforceable for all time. In B. Braun Medical, Inc. v. Abbott Laboratories, this court stated:

[T] he patent misuse doctrine is an extension of the equitable doctrine of unclean hands, whereby a court of equity will not lend its support to enforcement of a patent that has been misused. Patent misuse arose, as an equitable defense available to the accused infringer, from the desire to restrain practices that did not in themselves violate any law, but that drew anticompetitive strength from the patent right, and thus were deemed to be contrary to public policy. When used successfully, this defense results in rendering the patent unenforceable until the misuse is purged.

124 F.3d 1419, 1427 (Fed. Cir. 1997). In light of the foregoing, we agree with Qualcomm that patent misuse does not render a patent unenforceable for all time. Contrary to Qualcomm's arguments, however, the limited scope of unenforceability in the patent misuse context does not necessarily lead to the conclusion that an unenforceability remedy is unavailable in the waiver context in the present case. Instead, we conclude that a district court may in appropriate circumstances order patents unenforceable as a result of silence in the face of an SSO disclosure duty, as long as the scope of the district court's unenforceability remedy is properly limited in relation to the underlying breach.

While the scope of an unenforceability remedy in the patent misuse context is limited to rendering the patent unenforceable until the misuse is purged, the scope of the district court's unenforceability remedy in the present case was not limited in relation to Qualcomm's misconduct in the SSO context. The basis for Broadcom's waiver defense was Qualcomm's conduct before the JVT during development of the H.264 standard, including intentional nondisclosure of patents that it knew "reasonably might be necessary" to practice the standard. The district court correctly recognized that the remedy for waiver in the SSO context should not be automatic, but should be fashioned to give a fair, just, and equitable response reflective of the offending conduct. In determining the appropriate equitable remedy in this case, the district court properly considered the extent of the materiality of the withheld information and the circumstances of the nondisclosure relating to the JVT proceedings. While we agree with the district court that there is an "obvious connection between the '104 and '767 patents and H.264 compliant products," we do not discern such a connection between the asserted patents and products that are not H.264-compliant, and neither party points us to any such connection.

Accordingly, based on the district court's findings, the broadest permissible unenforceability remedy in the circumstances of the present case would be to render the '104 and '767 Patents (and their continuations, continuations-in-part, divisions, reissues, and any other derivatives thereof) unenforceable against all H.264-compliant products (including the accused products in this case, 
as well as any other current or future H.264-compliant products). Accordingly, we vacate the unenforceability remedy and remand with instructions to enter an unenforceability remedy limited in scope to any H.264-compliant products.

\section{NOTES AND QUESTIONS}

1. Rambus v. Infineon. Perhaps the best-known case of a failure to disclose patents to an SDO Rambus, Inc., a developer of semiconductor memory technology. Much has been written about the decade-long legal battles in which Rambus sought to assert its patents against implementers of dynamic random access memory (DRAM) technology standardized by the Joint Electron Device Engineering Council (JEDEC), a voluntary SDO in which Rambus participated in the early 1990s. In the cases (which involved U.S. and EU enforcement agencies, as well as multiple semiconductor companies), Rambus escaped liability largely because some (but not all) of the triers of fact determined that that the JEDEC patent policy was too vague to prohibit the conduct that Rambus was alleged to have committed. Or, as concluded by the Federal Circuit in Rambus v. Infineon (Fed. Cir. 2003), the JEDEC policy suffered from "a staggering lack of defining details" that left SDO participants with "vaguely defined expectations as to what they believe the policy requires." In hindsight, it is easy to criticize JEDEC and its counsel for poor drafting, but can you think of any factors that might have led to the deliberate creation of such an imprecise policy?

2. Policy Language. The outcome of Broadcom hangs on whether or not Qualcomm had a duty to disclose two of its patents to JVT. The court concedes that the language of JVT's patent policy does not expressly create this obligation, yet imposes this obligation on Qualcomm based on the general understanding of JVT participants. Is it valid to impose a legal obligation based on non-lawyers' (mis)understanding of legal policies? How does the court reconcile its holding with that of Rambus $v$. Infineon, in which no duty to disclose was found under a similarly unclear policy?

3. Non-infringement. At the district court, the jury found that Qualcomm's patents were not infringed by Broadcom. What does this finding imply regarding the essentiality of Qualcomm's patents to the H.264 standard? Why did the Federal Circuit give little weight to the jury's noninfringement finding or Qualcomm's argument that, as a result, Broadcom suffered no harm from Qualcomm's failure to disclose the patents at issue?

4. Unenforceability. In Broadcom, the district court held that Qualcomm's undisclosed patents were unenforceable as against the entire world. The Federal Circuit vacated this holding and remanded to narrow the scope of the unenforceability remedy. Was this a victory for Qualcomm? What practical difference is there between an unenforceability order as to the entire world and as to a standard with respect to which the patent is essential? But even with the Federal Circuit's narrowing of the district court's unenforceability order, patent unenforceabilty is a remarkably strong remedy. Was this remedy justified in this case? Why?

5. Nondisclosure as an Antitrust Violation? After the Federal Circuit's 2003 ruling in favor of Rambus in Rambus $v$. Infineon, the Federal Trade Commission initiated a separate action against Rambus, arguing that its failure to disclose relevant patents to the JEDEC SDO violated U.S. antitrust law. In 2006, the FTC ruled against Rambus, finding that it had violated both the Sherman Act and the FTC Act through its deceptive conduct toward JEDEC. The FTC's ruling was 
overturned on technical antitrust grounds in 2008 by the Court of Appeals for the DC Circuit. ${ }^{13}$ Nevertheless, it is still generally understood that an SDO participant's intentional failure to disclose relevant patents to the SDO in violation of its policies is likely to constitute a violation of the antitrust laws.

6. Disclosure of Licensing Terms. The disclosure policies at issue in the Rambus and Broadcom cases discussed above concern the disclosure of patents that are (or may be) essential to the implementation of technical standards. In addition, at least one $\mathrm{SDO}^{14}$ has adopted a policy requiring the disclosure not only of patents essential to its standards, but also the most restrictive licensing terms (i.e., the highest royalty rates) on which the patent holder will license those patents to others. Surprisingly, such "ex ante" licensing disclosure policies have proven extremely controversial and have been vehemently opposed by patent holders at other SDOs. Why do you think that a patent holder would object to disclosing its licensing terms for standards-essential patents? ${ }^{15}$

\section{FRAND Royalty Rates}

One of the most complex issues arising with respect to FRAND licensing is the royalty level that complies with a SEP holder's commitment to grant a license on terms that are "fair and reasonable". As noted above, most SDOs offer little guidance regarding the actual FRAND royalty level. Thus, the determination of FRAND royalty rates is typically left to bilateral negotiations among SEP holders and manufacturers of standardized products. Not surprisingly, there is sometimes disagreement whether a royalty rate is compliant with the SEP holder's FRAND commitment. In some cases, a SEP holder and a manufacturer may disagree whether the royalty rate demanded by the SEP holder for such a license is FRAND, and the manufacturer may sue the SEP holder for breaching its FRAND commitment. In other cases, a SEP holder may sue a manufacturer for infringing its SEPs, and the manufacturer may raise as an affirmative defense the SEP holder's obligation to grant the manufacturer a license on FRAND terms. In both of these scenarios, one of the central questions is whether the royalty rate that the SEP holder sought to charge the manufacturer was FRAND.

\section{FRAND Royalties in the U.S. and the Georgia-Pacific Framework}

Under the U.S. Patent Act, the principal measure of damages for patent infringement is a "reasonable royalty". As a result, several courts that have calculated FRAND royalty rates have looked to traditional methodologies for determining reasonable royalty damages. The calculation of reasonable royalty damages in the U.S. has generally followed the 15-factor framework established in 1970 by Georgia-Pacific Corp. v. U.S. Plywood Corp., 318 F. Supp. 1116 ( S.D.N.Y. 1970). However, because this framework assumes that the patent holder and the infringer have no pre-existing relationship, and that the patent holder is not otherwise constrained in its ability to

\footnotetext{
${ }^{13}$ Rambus Incorporated v. FTC, 522 F.3d 456 (D.C. Cir. 2008).

${ }^{14}$ VITA, the VMEBus International Trade Association, a small SDO that develops electronics standards for avionics and defense applications.

${ }^{15}$ For a discussion of the controversy surrounding this issue, see Jorge L. Contreras, Technical Standards and Ex Ante Disclosure: Results and Analysis of an Empirical Study, 53 Jurimetrics 163 (2013).
} 
determine its royalty rate, many of the assumptions underlying the Georgia-Pacific analysis do not apply in cases involving FRAND-encumbered SEPs.

In Microsoft v. Motorola, the Federal District Court for the Western District of Washington sought to determine both a reasonable royalty and a range of reasonable royalties for Motorola's patents covering two industry standards. In doing so, the court looked first to the reasonable royalty damages analysis in Georgia-Pacific, including its hypothetical negotiation framework. He reasoned that the parties to a hypothetical negotiation would set [F]RAND ${ }^{16}$ royalty rates by "looking at the importance of the SEPs to the standard and the importance of the standard and the SEPs to the products at issue". However, he also noted that "[f]rom an economic perspective, a RAND commitment should be interpreted to limit a patent holder to a reasonable royalty on the economic value of its patented technology itself, apart from the value associated with incorporation of the patented technology into the standard".

Ultimately, the court adopted a modified version of the Georgia-Pacific framework in which it altered twelve of the fifteen factors to take Motorola's RAND commitment into account. After establishing this analytical framework, the court looked to several "comparable" sets of license agreements, including some patent pools, to evaluate the basis for Motorola's RAND royalty rates.

The RAND royalty rates determined by the court in Microsoft were significantly lower than the rates originally demanded by Motorola. For example, with respect to SEPs covering the H.264 audio-video encoding standard, Motorola initially demanded a royalty of $2.25 \%$ of the end price of Microsoft products embodying the standard. Thus, for a low-end $\$ 500$ computer, the per-unit royalty would have been $\$ 11.25$. The court, in assessing the value of Motorola's patents to the H.264 standard and the value of the standard to the overall products in which it was embodied, determined a FRAND royalty rate of $\$ 0.00555$ per unit. Based on these results, Motorola's initial royalty demand to Microsoft was more than 2,000 times higher than the "reasonable" royalty rate determined by the court.

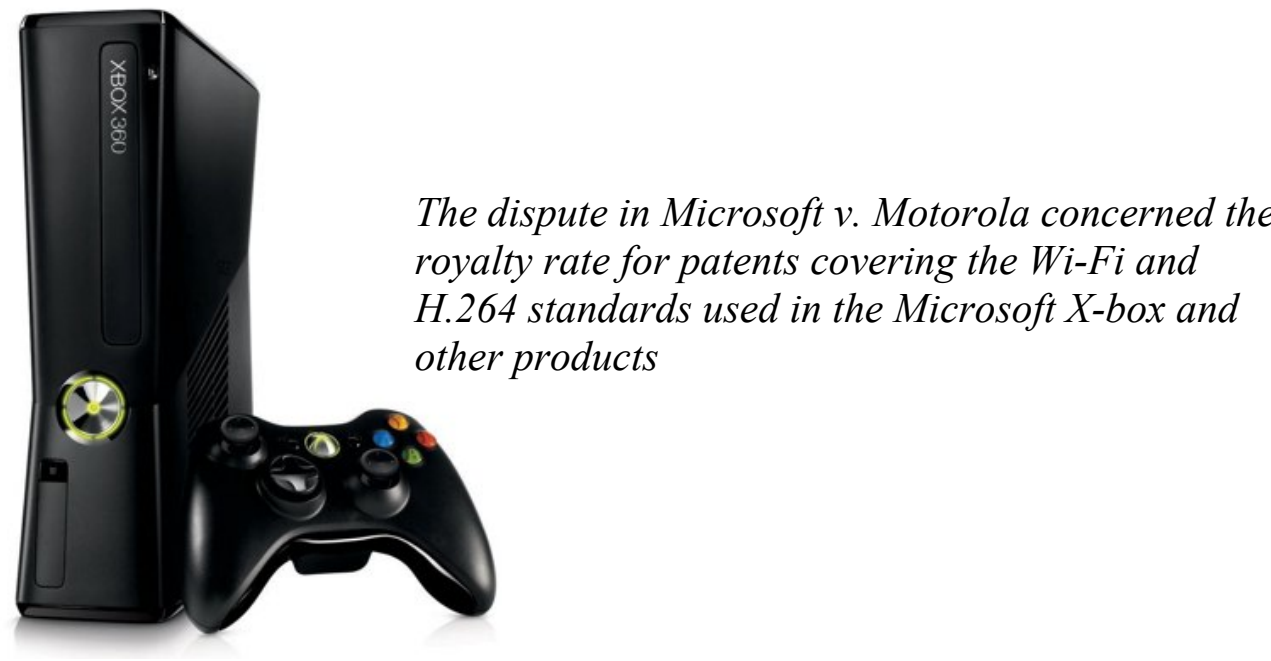

In Innovatio IP Ventures, 956 F. Supp. 2d 925 (N.D.Ill. 2013), Innovatio, a patent assertion entity (PAE) holding twenty-three SEPs covering the $802.11 \mathrm{Wi}-\mathrm{Fi}$ standards sent demand letters

${ }^{16}$ Most courts and commentators who have considered the issue use the terms FRAND and RAND interchangeably. 
to hundreds of coffee shops, motels, supermarkets and other retail establishments that offered public Wi-Fi access (thereby allegedly infringing the SEPs), in each case seeking a modest monetary settlement. The case was consolidated and the court considered Innovatio's proposed royalty of $6 \%$ of the end price of products such as wireless access points, laptops, tablets and bar code scanners, resulting in potential royalties ranging from $\$ 3.39$ to $\$ 36.90$ per unit. In assessing the appropriate RAND royalty rate, the District Court for the Northern District of Illinois largely followed the framework described in Microsoft for the determination of RAND royalties. In particular, it applied a modified Georgia-Pacific analysis that simulates a hypothetical bilateral negotiation in the context of RAND obligations. After assessing the value of Innovatio's SEPs, the court held that the appropriate FRAND royalty was only $\$ 0.0956$ per unit, making Innovatio's initial royalty proposals between 35 and 386 times higher than the adjudicated FRAND royalty rate.

In Ericsson v. D-Link, 773 F.3d 1201, 1226 (Fed. Cir. 2014), the FRAND royalty rate was determined by a jury. Thus, the Federal Circuit, on appeal, was limited to reviewing the trial court's instructions to the jury. In the appeal, the Federal Circuit reversed and remanded the jury verdict based, in part, on the district court's instruction to apply the fifteen Georgia-Pacific factors without modification. The Federal Circuit affirmed that, "[i]n a case involving RAND-encumbered patents, many of the Georgia-Pacific factors simply are not relevant; many are even contrary to RAND principles". The Federal Circuit noted several respects in which the Georgia-Pacific factors were both irrelevant and contrary to the RAND commitment under consideration. Thus, like the court in Microsoft, the Federal Circuit criticized the use of several specific Georgia-Pacific factors when considering royalties subject to RAND commitments.

The Federal Circuit in Ericsson v. D-Link made several other important rulings. In particular, it held that an accused infringer seeking to raise the issue of hold-up to a jury must introduce actual evidence of the SEP holder's hold-up behavior. Because this evidence was not introduced by the alleged infringer, the court was justified in not instructing the jury on the question of hold-up. The court used similar reasoning with respect to the question of royalty stacking and held that actual evidence of stacking must be introduced in order for the question to be considered by the jury.

\section{Bottom-Up versus Top-Down Royalty Determinations}

In most of the cases discussed in Part A above, the courts determined FRAND royalties in a "bottom-up" manner. That is, they calculated the royalty due to the patent holder based primarily on the alleged value of the patents in suit, without regard to the overall number or value of patents covering the standard in question or the results reached by other courts addressing the same standards. In fact, as the Federal Circuit emphasized in Ericsson v. D-Link, a court may not even instruct the jury regarding royalty stacking without actual evidence of stacking. When such bottom-up approaches are used, royalties due to individual patent holders are determined in an uncoordinated manner independently of one another, and the total royalty burden associated with a standard emerges only as the sum of its individual components. The problem with such bottomup approaches is that courts may use different royalty criteria and factors case by case, even when patents covering the same features of the same standard are involved, thus yielding inconsistent and potentially excessive results. For example, as shown in Table 1, in 2013 and 2014, five different U.S. district courts calculated royalties for a total of 35 SEPs covering IEEE's Wi-Fi standards using different methodologies, with widely divergent results. 
TABLE 1

U.S. Litigated FRAND Royalty Determinations for 802.11 (Wi-Fi) Standard-Essential Patents ${ }^{17}$

\begin{tabular}{|c|c|c|}
\hline Case & Court (year) & Royalty \\
\hline Microsoft v. Motorola & W.D. Wash. (2013) & $\$ 0.035$ per unit \\
\hline In re Innovatio & N.D. Ill. (2013) & $\$ 0.0956$ per unit \\
\hline Ericsson $v$. D-Link & E.D. Tex. (2013) & $\$ 0.15$ per unit \\
\hline Realtek v. LSI & N.D. Cal. (2014) & $0.12 \%$ of net sales \\
\hline CSIRO v. Cisco & E.D. Tex. (2014) & Up to \$1.90 per unit \\
\hline
\end{tabular}

The aggregate royalty for these 35 SEPs amounted to approximately $4.5 \%$ of the total sale price of a typical $\$ 50 \mathrm{Wi}-\mathrm{Fi}$ router. Yet it has been estimated that there are approximately 3,000 patents covering the Wi-Fi standard. If the royalty for each of these patents were calculated in a similarly uncoordinated, bottom-up manner, the aggregate patent royalty on a Wi-Fi router could easily surpass the product's total selling price by at least an order of magnitude. And even if, as suggested by some commentators, this effect might be reduced because many of these SEPs are held by the same large firms, the total number of firms holding SEPs covering Wi-Fi is still significantly larger than the number of adjudicated cases to date.

Given the growing recognition of these issues, commentators, courts and policy makers have become increasingly attracted to mechanisms that take into account the aggregate royalty burden associated with a standard when considering the royalties owed to any particular patent holder. Thus, as noted by the European Commission in a recent communication regarding SEPs, "an individual SEP cannot be considered in isolation. Parties need to take into account a reasonable aggregate rate for the standard, assessing the overall added value of the technology." Royalty calculation methodologies that seek to address these issues can broadly be termed "top-down" approaches because they look first to the overall level of royalties associated with a standard and then allocate a portion of this total to individual patent holders. Top-down approaches implicitly recognize that when multiple patents cover a single standard, the rate charged by one SEP holder will necessarily affect the rates that the other SEP holders are able to obtain from a given manufacturer. Of course, the biggest challenge of a top-down approach is determining the overall royalty rate for the patents covering a particular standard.

\section{NOTES AND QUESTIONS}

1. Top Down v. Bottom Up. What are the relative advantages and drawbacks of top-down and bottom-up approaches to calculating FRAND royalties? Do these advantages and drawbacks apply to patents other than SEPs?

2. Vive la différence? Are there advantages or disadvantages to the multiple methods of calculating FRAND royalties recognized by the courts? How might different judicial approaches

${ }^{17}$ Jason R. Bartlett and Jorge L. Contreras, Rationalizing FRAND Royalties: Can Interpleader Save the Internet of Things, 36 REVIEW OF LITIGATION 285, 288 (2017) (citations omitted). 
to FRAND royalty calculation influence licensing negotiations among SEP holders and manufacturers of standardized products?

3. Third Party Beneficiaries. In general, a FRAND commitment is made by a SEP holder as part of its agreement to participate in an SDO, whether through a written membership agreement, the SDO's corporate bylaws, or a formal policy adopted by the SDO's board or membership. In all of these cases, the SEP holder's formal commitment runs to the SDO rather than to third party manufacturers of standardized products. Yet it is precisely those manufacturers who will benefit most directly from the SEP holder's commitment: they are the ones to which the SEP holder must grant licenses on FRAND terms. More importantly, it is they, rather than the SDOs themselves, who are far more likely to seek to enforce a SEP holder's FRAND commitment in court. Do you understand why this is the case?

As a result of this mismatch, manufacturers seeking to enforce FRAND commitments against SEP holders have often sought to do so as intended third party beneficiaries of the SEP holders' FRAND commitments. As described in Section 301 of the Restatement (Second) of Contracts,

Unless otherwise agreed between promisor and promisee, a beneficiary of a promise is an intended beneficiary if recognition of a right to performance in the beneficiary is appropriate to effectuate the intention of the parties and ... the circumstances indicate that the promisee intends to give the beneficiary the benefit of the promised performance.

What challenges might a product manufacturer face in seeking to enforce a SEP holder's FRAND commitment as a third party beneficiary? ${ }^{18}$ What if some countries do not recognize a third party beneficiary doctrine in their contract law? ${ }^{19}$

\footnotetext{
${ }^{18}$ See Contreras, Market Reliance, supra note 7, at 508-14.

${ }^{19}$ According to Professor Thomas Cotter, courts outside the United States have not found contract theory to be a particularly strong theory of enforcing FRAND commitments (especially with regard to third-party beneficiary status). See Thomas F. Cotter, Comparative Law and Economics of Standard-Essential Patents and FRAND Royalties, 22 Tex. Intell. Prop. L.J. 311 (2014) (discussing cases from Germany, the Netherlands, and the Republic of Korea).
} 


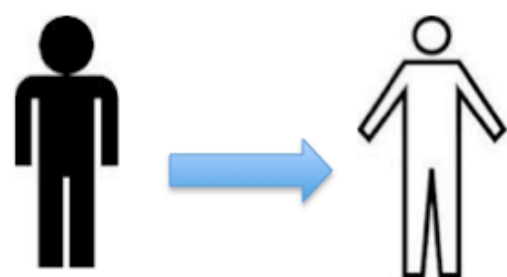

(A) Contract Paradigm - Black to White: "I will grant you a license"

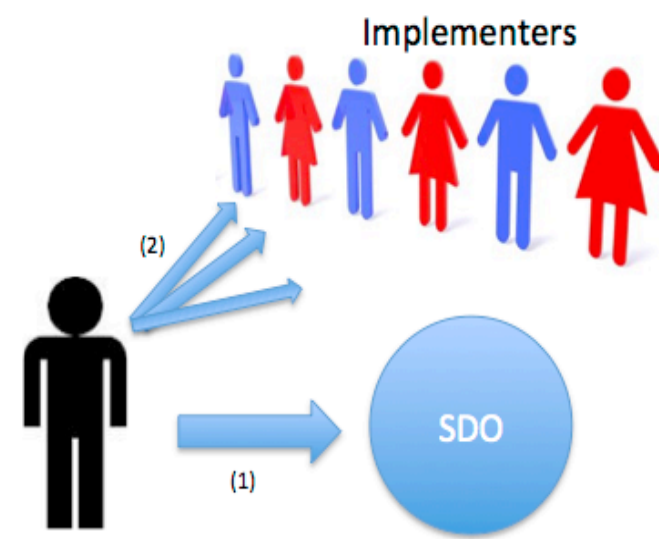

(B) Standards Paradigm - Black to SDO "I will grant Implementers a license"

4. Royalty-Free Standards. Not all SEPs are licensed on FRAND terms. In fact, SEPs covering broadly adopted standards such as USB, Bluetooth, HTML, HTTP, the Worldwide Web and the Internet Protocol are all made available on a royalty-free basis. Why would the SDOs behind these standards, and its members, choose this approach? Is this corporate philanthropy, or are there commercial reasons to release a standard on a royalty-free basis? And if it works for them, why aren't all SEPs licensed on a royalty-free basis? ${ }^{20}$

5. Disclosure versus Licensing Commitments. Not all SDOs require their participants to license SEPs, whether on FRAND or any other terms. The principal example of such an SDO is IETF, which requires its participants to disclose any of their patents or patent applications that may cover an IETF standard that they have helped to develop, but does not require them to license those patents to anyone. Is this a major oversight, or can you think of a reason that IETF may have adopted this approach? ${ }^{21}$ Despite IETF's lack of a patent licensing commitment, most IETF participants voluntarily commit to license their patents to implementers of IETF standards on a royalty-free basis. What might motivate companies to do this?

\section{Non-Discrimination and FRAND Commitments}

The terms offered under a FRAND license must be not only fair and reasonable, but "nondiscriminatory". Like "fair" and "reasonable", there is significant debate concerning the meaning and contours of the obligation to grant licenses on terms that are "non-discriminatory".

There is a general consensus that in order to comply with the non-discrimination prong of the FRAND commitment, a SEP holder must treat "similarly situated" licensees in a similar manner. Several commentators have understood this constraint to allow a SEP holder to charge different

\footnotetext{
${ }^{20}$ For a discussion of this issue and its manifestation in two related but very different industries - wireless telecommunications and the Internet, see Jorge L. Contreras, A Tale of Two Layers: Patents, Standards and the Internet, 93 Denver L. Rev. 855 (2016).

${ }^{21}$ See id.
} 
royalty rates to implementers based on their size or market share (often with the understanding that larger players are likely to sell more licensed products and thus pay higher levels of royalties). In Unwired Planet v. Huawei, the UK High Court for Patents reasons that a FRAND royalty rate should be set based on the value of the licensed patents, not on the size of other characteristics of the licensee. Thus, "all licensees who need the same kind of licence will be charged the same kind of rate" and "[s]mall new entrants are entitled to pay a royalty based on the same benchmark as established large entities".

\section{Hard-Edged Non-Discrimination}

In Unwired Planet, the UK court asks what happens if, after a FRAND rate is agreed between a SEP holder and an implementer, the implementer discovers that the SEP holder has, previously or subsequently, granted more favorable terms (i.e., a lower royalty rate) to another "similarly situated" implementer? Has the SEP holder violated its nondiscrimination commitment? Interestingly, the court rules that a SEP licensee cannot challenge a license granted to it on FRAND terms if it later discovers that a similarly-situated licensee is paying a lower rate for the same patents unless the difference would "distort competition" between the two licensees. In reaching this conclusion, the court rejects the notion that the ND prong of FRAND implies a "hard-edged" obligation that places an absolute ceiling on the rate that a SEP holder may charge to other licensees. That is, some level of "discrimination" might be permitted, so long as the discrepancy between rates does not distort competition.

\section{Level Discrimination}

One of the most hotly debated issues concerning the ND prong of FRAND is whether a FRAND commitment requires a SEP holder to grant a license to all applicants, or whether the SEP holder may refuse to license certain categories of potential licensees (usually "upstream" component vendors) so that they may instead license other categories of licensees (usually "downstream" product vendors that purchase components from upstream vendors). This approach is largely motivated by the doctrine of patent exhaustion (see Chapter 23), under which a patent holder may collect a royalty only once per patented article. Thus, if a standardized technology is implemented in a chip, the SEP holder may collect a royalty either from the manufacturer of the chip, the assembler of the circuit board on which the chip resides, the producer of the smartphone in which the board is installed or the user of the smart phone that utilizes the chip. But it cannot collect royalties from more than one of these parties in the supply chain. The SEP is "exhausted" once a product is sold by an authorized licensee, and the SEP holder cannot collect royalties from further downstream users of the patented technology.

There is thus a significant debate regarding the ability of SEP holders, under their FRAND commitments, to refuse to grant licenses to upstream component manufacturers who seek SEP licenses. Courts and commentators are divided on this issue. The U.S. Court of Appeals for the Ninth Circuit held in Microsoft v. Motorola that a SEP holder, in its declarations to the ITU, promised to "grant a license to an unrestricted number of applicants on a worldwide, nondiscriminatory basis". Likewise, the district court in FTC v. Qualcomm, 2018 U.S. Dist. LEXIS 190051, *11-12 (N.D. Cal. 2018), found that the policies of two SDOs, the Telecommunications 
Industry Association (TIA) and the Alliance for Telecommunications Industry Solutions (ATIS), required Qualcomm to grant licenses to "all applicants". ${ }^{22}$

Nevertheless, some have argued that the "non-discrimination" prong of FRAND does not require SEP holders to offer licenses to every applicant, but only to avoid discrimination within the class of applicants that the SEP holder chooses to license. SEP holders who refuse to license component vendors have argued that by instead licensing such component vendors' downstream customers, they have, in effect, "indirectly licensed" the component vendors, and that refusing to license component vendors does not discriminate against competitors. In other words, so long as no component vendors receive licenses, no one component maker is placed at a competitive disadvantage compared to the others. This approach was seemingly validated by the district court in Ericsson v. D-Link, which held that Ericsson did not violate its non-discrimination covenant by offering licenses only to vendors of "fully compliant" products and refusing to license chip and component vendors.

\section{NOTES AND QUESTIONS}

1. U.S. versus $U K$. As with so many things (chips v. fries, hood v. bonnet, football v. soccer), the British and American approaches to non-discrimination in FRAND licenses seem to be at odds with one another. Does this trans-Atlantic divergence matter? Why? ${ }^{23}$

2. Making Policies Clear. The reader should by now have realized that if SDO policies were more explicit about their requirements, disagreements like the ones described in this section would be less likely to occur. As the National Academies of Science observed:

Ideally, SSO policies should clarify the nature of rights and obligations transferred with an SEP in a manner that promotes widespread implementation of standards without creating additional transaction costs that could impede the otherwise efficient transfer of patent rights. To achieve that balance, SSOs need to consider both the legal implications of their IPR policies and their practical effects on different stakeholders. ${ }^{24}$

Some SDOs have sought to clarify their IP policies. For example, in 2015 the IEEE amended its IP policy to describe various expectations associated with its FRAND commitment, including an express obligation to grant SEP licenses to all applicants. Why don't more SDOs clarify their policies to avoid disagreement over their meaning and intent? What vested interests do you think might work against clarity of SDO policies? The IEEE's 2015 policy amendments were met with fierce opposition. Who do you think opposed them and why?

\footnotetext{
${ }^{22}$ This ruling was later vacated by the Ninth Circuit as moot. FTC v. Qualcomm, slip op. at *20 (9 ${ }^{\text {th }}$ Cir., Aug. 11, 2020).

${ }^{23}$ For a discussion of the implications of divergent national approaches to global FRAND licenses, see Jorge L. Contreras, The New Extraterritoriality: FRAND Royalties, Anti-Suit Injunctions and the Global Race to the Bottom in Disputes over Standards-Essential Patents, 25(2) B.U. J. Sci. \& Tech. L. 251 (2019).

${ }^{24}$ Natl. Research Council, Intellectual Property Challenges For Standard-Setting In the Global Economy 83 (Keith Maskus \& Stephen A. Merrill, eds., Natl. Acad. Press 2013).
} 
3. The Origin of Patent Access Requirements. Commitments to license patents on FRAND terms have their origin in a series of antitrust remedial orders extending back to the early 1940s. These orders were put in place to remedy a range of anticompetitive arrangements that patent holders had created using their patents. More than one hundred such orders were entered by the 1970 s. $^{25}$ Today's FRAND obligations are different, as they are voluntary commitments made by participants in SDOs. If the commitment is the same, does it matter that one is imposed by a court but the other is made voluntarily? Should these commitments be interpreted in a similar manner, or does the voluntary nature of today's FRAND commitments make them so unlike their mandatory predecessors that comparison is unwarranted?

\section{E. Effect of a FRAND Commitment on Injunctive Relief}

One of the remedies available to a patent holder when its patent is infringed is an injunction a court order that prohibits the infringer from continuing to infringe the patent. Often, the entry of an injunction means that the infringer may no longer manufacturer or sell the infringing product, or that it must design around the patent so that the product no longer infringes. But what happens when a product implements a widely-adopted industry standard and infringes a SEP that the SEP holder has committed to license on FRAND terms? May the patent holder seek or obtain an injunction blocking the manufacturer from making and selling the standardized product?

The analysis of injunctive relief in U.S. patent cases takes its current form from the landmark U.S. Supreme Court decision in eBay Inc. v. MercExchange, L.L.C., 547 U.S. 388 (2006). In eBay the Court held that the decision to grant or deny an injunction is an act of judicial discretion that must be exercised in accordance with "well-established principles of equity". The Court articulated a four-factor equitable test to be applied by courts considering the grant of injunctive relief. This test requires the plaintiff seeking an injunction to demonstrate:

1. that it has suffered an irreparable injury;

2. that remedies available at law [i.e., monetary damages] are inadequate to compensate it for that injury;

3. that considering the balance of hardships between the plaintiff and defendant, a remedy in equity is warranted; and

4. that the public interest would not be disserved by the award of an injunction.

In view of these factors, some have argued that a SEP holder, by making a FRAND commitment, implicitly concedes that remedies available at law (i.e., monetary damages) must be adequate to compensate it for the infringement. They reason that, by committing to grant everyone a license on FRAND terms, the SEP holder has agreed not to exclude others from the market, but only to collect only a "reasonable" royalty to compensate it for the infringement of its SEPs. As a result, they argue that the second $e$ Bay factor can never be satisfied by a patent holder that has made a FRAND commitment, and therefore such a SEP holder should generally be precluded from seeking injunctive relief to prevent others from operating under its SEPs. The interplay of FRAND

${ }^{25}$ See Jorge L. Contreras, A Brief History of FRAND: Analyzing Current Debates in Standard-Setting and Antitrust through a Historical Lens, 80 Antitrust L.J. 39 (2015). 
commitments with the U.S. law of patent injunctions has given rise to several judicial decisions as well as guidance from regulatory and enforcement agencies in the U.S.

In Microsoft Corp. v. Motorola, Inc., Motorola sought an injunction to prevent Microsoft's continued infringement of Motorola's patents covering two industry standards (IEEE's 802.11 and ITU's H.264) as to which Motorola made FRAND commitments. The court evaluated Motorola's request for an injunction in view of the four $e B a y$ factors and determined that Motorola did not suffer an irreparable injury or show that monetary damages would be inadequate to compensate it for the infringement. Accordingly, the court denied Motorola's request for an injunction.

In Realtek Semiconductor Corp. v. LSI Corp., the U.S. District Court for the Northern District of California held that a SEP holder breached its FRAND commitment by seeking injunctive relief against an implementer of a standard before the patent holder offered a license to the implementer. Again, the injunction was denied.

These district court decisions laid the groundwork for the Court of Appeals for the Federal Circuit to consider the issue of injunctive relief in Apple, Inc. v. Motorola, Inc., in which the district judge (Richard Posner, sitting by designation from the Seventh Circuit) denied Motorola's request for an injunction against Apple's sale of products that allegedly infringed a SEP covering part of the UMTS 3G wireless telecommunications standard published by the European Telecommunications Standards Association (ETSI). The fractured, 3-way opinion of the Federal Circuit is excerpted below.

\section{APPLE, INC. V. MOTOROLA, INC.}

757 F.3d 1286 (Fed. Cir. 2014)

\section{REYNA, CIRCUIT JUDGE.}

Apple moved for summary judgment that Motorola was not entitled to an injunction for infringement of the ' 898 patent. The ' 898 patent is a SEP and, thus, Motorola has agreed to license it on fair, reasonable, and non-discriminatory licensing ("FRAND") terms. The district court granted Apple's motion, stating:

I don't see how, given FRAND, I would be justified in enjoining Apple from infringing the ' 898 unless Apple refuses to pay a royalty that meets the FRAND requirement. By committing to license its patents on FRAND terms, Motorola committed to license the ' 898 to anyone willing to pay a FRAND royalty and thus implicitly acknowledged that a royalty is adequate compensation for a license to use that patent. How could it do otherwise? How could it be permitted to enjoin Apple from using an invention that it contends Apple must use if it wants to make a cell phone with UMTS telecommunications capability-without which it would not be a cell phone.

To the extent that the district court applied a per se rule that injunctions are unavailable for SEPs, it erred.

While Motorola's FRAND commitments are certainly criteria relevant to its entitlement to an injunction, we see no reason to create, as some amici urge, a separate rule or analytical framework 
for addressing injunctions for FRAND-committed patents. The framework laid out by the Supreme Court in eBay, as interpreted by subsequent decisions of this court, provides ample strength and flexibility for addressing the unique aspects of FRAND committed patents and industry standards in general. A patentee subject to FRAND commitments may have difficulty establishing irreparable harm. On the other hand, an injunction may be justified where an infringer unilaterally refuses a FRAND royalty or unreasonably delays negotiations to the same effect. To be clear, this does not mean that an alleged infringer's refusal to accept any license offer necessarily justifies issuing an injunction. For example, the license offered may not be on FRAND terms. In addition, the public has an interest in encouraging participation in standard-setting organizations but also in ensuring that SEPs are not overvalued. While these are important concerns, the district courts are more than capable of considering these factual issues when deciding whether to issue an injunction under the principles in $e B a y$.

Applying those principles here, we agree with the district court that Motorola is not entitled to an injunction for infringement of the ' 898 patent. Motorola's FRAND commitments, which have yielded many license agreements encompassing the '898 patent, strongly suggest that money damages are adequate to fully compensate Motorola for any infringement. Similarly, Motorola has not demonstrated that Apple's infringement has caused it irreparable harm. Considering the large number of industry participants that are already using the system claimed in the '898 patent, including competitors, Motorola has not provided any evidence that adding one more user would create such harm. Again, Motorola has agreed to add as many market participants as are willing to pay a FRAND royalty. Motorola argues that Apple has refused to accept its initial licensing offer and stalled negotiations. However, the record reflects that negotiations have been ongoing, and there is no evidence that Apple has been, for example, unilaterally refusing to agree to a deal. Consequently, we affirm the district court's grant of summary judgment that Motorola is not entitled to an injunction for infringement of the ' 898 patent.

\section{RADER, CHIEF JUDGE, DISSENTING-IN-PART.}

I join the court's opinion in its entirety, except for the affirmance of the district court's denial of Motorola's request for an injunction. To my eyes, the record contains sufficient evidence to create a genuine dispute of material fact on Apple's posture as an unwilling licensee whose continued infringement of the '898 patent caused irreparable harm. Because of the unique and intensely factual circumstances surrounding patents adopted as industry standards, I believe the district court improperly granted summary judgment. Therefore, on this narrow point, I respectfully dissent in part.

At the outset, a patent adopted as a standard undoubtedly gains value by virtue of that adoption. This enhancement complicates the evaluation of the technology independent of the standardization. By the same token, the standardization decision may also simply reflect and validate the inherent value of the technology advance accomplished by the patent. Untangling these value components (at the heart of deciding whether a putative licensee was "unwilling" to license, and thus irreparable harm and other injunction factors) requires intense economic analysis of complex facts. In sum, right from the theoretical outset, this question is not likely to be susceptible to summary adjudication.

In reciting the legal principles for an injunction, this court accurately states the inquiries. Those principles supply no per se rule either favoring or proscribing injunctions for patents in any setting, 
let alone the heightened complexity of standardized technology. This court notes that a patent owner in a standard context "may have difficulty establishing irreparable harm ... [but] an injunction may be justified where an infringer unilaterally refuses a FRAND royalty or unreasonably delays negotiations to the same effect."

Market analysts will no doubt observe that a "hold out" (i.e., an unwilling licensee of an SEP seeking to avoid a license based on the value that the technological advance contributed to the prior art) is equally as likely and disruptive as a "hold up" (i.e., an SEP owner demanding unjustified royalties based solely on value contributed by the standardization). These same complex factual questions regarding "hold up" and "hold out" are highly relevant to an injunction request. In sum, differentiating "hold up" from "hold out" requires some factual analysis of the sources of value - the inventive advance or the standardization.

The record in this case shows evidence that Apple may have been a hold out. This evidence alone would create a dispute of material fact.

More important, the district court made no effort to differentiate the value due to inventive contribution from the value due to standardization. Without some attention to that perhaps dispositive question, the trial court was adrift without a map, let alone a compass or GPS system. In fact, without that critical inquiry, the district court could not have properly applied the eBay test as it should have.

Instead of a proper injunction analysis, the district court effectively considered Motorola's FRAND commitment as dispositive by itself: "Motorola committed to license the '898 to anyone willing to pay a FRAND royalty and thus implicitly acknowledged that a royalty is adequate compensation for a license to use that patent. How could it do otherwise?" To the contrary, Motorola committed to offer a FRAND license, which begs the question: What is a "fair" and "reasonable" royalty? If Motorola was offering a fair and reasonable royalty, then Apple was likely "refus[ing] a FRAND royalty or unreasonably delay[ing] negotiations." In sum, the district court could not duck the question that it did not address; was Motorola's FRAND offer actually FRAND?

Furthermore, the district court acknowledged the conflicting evidence about Apple's willingness to license the ' 898 patent: "Apple's refusal to negotiate for a license (if it did refusethe parties offer competing accounts, unnecessary for me to resolve, of why negotiations broke down) was not a defense to a claim by Motorola for a FRAND royalty." Yet this scenario, adequately presented by this record, is precisely one that the court today acknowledges may justify an injunction.

In my opinion, the court should have allowed Motorola to prove that Apple was an unwilling licensee, which would strongly support its injunction request. The court states that "the record reflects that negotiations have been ongoing," but, as the district court even acknowledged, Motorola asserts otherwise - that Apple for years refused to negotiate while nevertheless infringing the ' 898 patent. Motorola should have had the opportunity to prove its case that Apple's alleged unwillingness to license or even negotiate supports a showing that money damages are inadequate and that it suffered irreparable harm. The district court refused to develop the facts necessary to apply eBay as it should have. Consequently, the case should be remanded to develop that record. For these reasons, I respectfully dissent in part. 


\section{PROST, CIRCUIT JUDGE, CONCURRING IN PART AND DISSENTING IN PART.}

I concur in the majority's judgment that Motorola is not entitled to an injunction for infringement of the ' 898 patent. However, I write separately to note my disagreement with the majority's suggestion that an alleged infringer's refusal to negotiate a license justifies the issuance of an injunction after a finding of infringement.

As an initial matter, I agree with the majority that there is no need to create a categorical rule that a patentee can never obtain an injunction on a FRAND-committed patent. Rather, FRAND commitment should simply be factored into the consideration of the $e B a y$ framework. Moreover, I agree that a straightforward application of the $e B a y$ factors does not necessarily mean that injunctive relief would never be available for a FRAND-committed patent. However, I disagree as to the circumstances under which an injunction might be appropriate.

Motorola argues - and the majority agrees - that an injunction might be appropriate where an alleged infringer "unilaterally refuses a FRAND royalty or unreasonably delays negotiations to the same effect." Motorola insists that in the absence of the threat of an injunction, an infringer would have no incentive to negotiate a license because the worst-case scenario from a patent infringement lawsuit is that it would have to pay the same amount it would have paid earlier for a license.

I disagree that an alleged infringer's refusal to enter into a licensing agreement justifies entering an injunction against its conduct, for several reasons. First, as Apple points out, an alleged infringer is fully entitled to challenge the validity of a FRAND-committed patent before agreeing to pay a license on that patent, and so should not necessarily be punished for less than eager negotiations. Second, there are many reasons an alleged infringer might prefer to pay a FRAND license rather than undergoing extensive litigation, including litigation expenses, the possibility of paying treble damages or attorney's fees if they are found liable for willful infringement, and the risk that the fact-finder may award damages in an amount higher than the FRAND rates. Indeed, as Motorola itself pointed out, we have previously acknowledged that a trial court may award an amount of damages greater than a reasonable royalty if necessary "to compensate for the infringement." Stickle v. Heublein, Inc., 716 F.2d 1550, 1563 (Fed. Cir. 1983). Thus, if a trial court believes that an infringer previously engaged in bad faith negotiations, it is entitled to increase the damages to account for any harm to the patentee as a result of that behavior.

But regardless, none of these considerations alters the fact that monetary damages are likely adequate to compensate for a FRAND patentee's injuries. I see no reason, therefore, why a party's pre-litigation conduct in license negotiations should affect the availability of injunctive relief.

Instead, an injunction might be appropriate where, although monetary damages could compensate for the patentee's injuries, the patentee is unable to collect the damages to which it is entitled. For example, if an alleged infringer were judgment-proof, a damages award would likely be an inadequate remedy. Or, if a defendant refused to pay a court-ordered damages award after being found to infringe a valid FRAND patent, a court might be justified in including an injunction as part of an award of sanctions. 
But regardless, these circumstances are not present in this case, and I agree with the district court that under the facts here, Motorola cannot show either irreparable harm or inadequacy of damages. I would therefore affirm the district court's denial of Motorola's claim for injunctive relief for the ' 898 patent.

\section{NOTES AND QUESTIONS}

1. Three Judges, Three Opinions. What is the crux of the Federal Circuit panelists' disagreement in Apple v. Motorola? Which of the judges do you most agree with?.

2. Holdout. In the plurality opinion in Apple v. Motorola, Judge Reyna comments that "an injunction may be justified where an infringer unilaterally refuses a FRAND royalty or unreasonably delays negotiations to the same effect." This type of bad faith behavior by potential licensees is often referred to as "holdout" or "reverse holdup". Chief Judge Rader argues that holdout "is equally as likely and disruptive as a "hold up"". Do you agree? Are hold-up and holdout just two sides of the same coin, or different types of wrongs?

3. Enhanced Damages for FRAND Violations? In her concurring opinion in Apple v. Motorola, Judge Prost makes that point that a SEP holder that is denied injunctive relief may not be entirely out of luck, as courts have the discretion to increase the damages awarded if the infringer engaged in bad faith negotiations. Is the likelihood of an enhanced damages award higher with respect to SEPs than other patents? Why? ${ }^{26}$

4. The FTC and Injunctive Relief. The Federal Trade Commission has also determined that a SEP holder subject to a FRAND commitment should be limited in its ability to seek injunctive relief from a potential SEP licensee. In late 2012 and 2013, the FTC brought actions under Section 5 of the FTC Act against Robert Bosch GmbH and Motorola Mobility (since acquired by Google) to address threats of injunctive relief against potential SEP licensees. The FTC's claims were settled by consent decrees in which the SEP holders agreed not to seek injunctive relief against infringers of FRAND-committed patents unless the infringer was beyond the jurisdiction of the U.S. courts, stated in writing that it would not accept a license of the patent, refused to enter into a license agreement determined by a court or arbitrator to comply with the FRAND requirement, or failed to provide written confirmation of an offer of a FRAND license. How do these exceptions square with the opinions in Apple v. Motorola?

5. The European Approach: Huawei v. ZTE. Under the national laws of some European countries, Germany in particular, injunctions are issued automatically once a patent holder establishes that its patent has been infringed, and prior to any adjudication of the validity of the asserted patent. This strong presumption in favor of injunctions is somewhat offset by the effect of Article 102 of the Treaty on the Functioning of the European Union (TFEU), which prohibits the "abuse of a dominant position". In some cases, dominance may be conferred by patent rights, and SEPs in particular. Thus, it is possible that a SEP holder's attempt to obtain an injunction against the manufacturer of a standardized product could constitute a violation of Article 102.

\footnotetext{
${ }^{26}$ For a discussion of this issue, see Jorge L. Contreras, et al., The Effect of FRAND Commitments on Patent Remedies, in Patent Remedies and Complex Products: Toward a Global Consensus, Ch. 5 (C. Bradford Biddle et al, eds., Cambridge Univ. Press: 2019, forthcoming).
} 
The analytical framework for assessing abuse of dominance with SEPs subject to FRAND commitments was established by the European Court of Justice (ECJ) in Huawei v. ZTE. In Huawei, the ECJ held that if a SEP holder possesses market dominance, then in order to avoid violating Article 102, the SEP holder must comply with a series of procedural steps. Likewise, in order to preserve its ability to challenge the SEP holder's conduct under Article 102, the infringer must comply with a similar series of procedural steps. The combination of these behavioral requirements has been referred to as the Huawei "choreography". The required steps in this choreography are summarized below:

1. The patentee must notify the defendant of the alleged infringement;

2. defendant must show its willingness to license on FRAND terms;

3. patentee must make a specific, written offer for a license on FRAND terms;

4. defendant must diligently respond to that offer without delaying tactics;

5. If defendant rejects the patentee's offer, it must make a counter-offer on FRAND terms; and

6. If patentee rejects the counter-offer, the defendant must provide appropriate security (including for past use) and be able to render an account of its acts of use.

In the few years since the Huawei decision, a number of cases in Germany and other jurisdictions have helped to clarify these requirements, though they seem to raise as many questions as they answer. ${ }^{27}$

6. Waiver. Given the legal uncertainty surrounding the availability of injunctive relief, particularly on an international basis, some SDOs have sought to address the issue in their IP policies. While an SDO's internal policies do not affect underlying legal rules, they can impose contractual restraints on its members' behavior and establish presumptions that can be considered by courts when assessing a request for injunctive relief. Below is an example of a contractual waiver of injunctive relief included in IEEE's patent policy (note that in IEEE, SEP holders make licensing commitments under written Letters of Assurance or LOAs):

\footnotetext{
${ }^{27}$ For a good summary of Huawei and subsequent cases, see Robin Jacob \& Alexander Milner, Lessons from Huawei v. ZTE, 4iP Council research report, Oct. 2016, http://www.4ipcouncil.com/news/latestresearch-4ip-council-lessons-huawei-v-zte.
} 


\section{IEEE STANDARDS ASSOCIATION}

\section{IEEE-SA Standards Board Bylaws (Dec. 2017)}

"Prohibitive Order" shall mean an interim or permanent injunction, exclusion order, or similar adjudicative directive that limits or prevents making, having made, using, selling, offering to sell, or importing a Compliant Implementation.

An Accepted LOA ... signifies that reasonable terms and conditions, including without compensation or under Reasonable Rates, are sufficient compensation for a license to use those Essential Patent Claims and precludes seeking, or seeking to enforce, a Prohibitive Order except as provided in this policy.

The Submitter of an Accepted LOA who has committed to make available a license for one or more Essential Patent Claims agrees that it shall neither seek nor seek to enforce a Prohibitive Order based on such Essential Patent Claim(s) in a jurisdiction unless the implementer fails to participate in, or to comply with the outcome of, an adjudication, including an affirming first-level appellate review, if sought by any party within applicable deadlines, in that jurisdiction by one or more courts that have the authority to: determine Reasonable Rates and other reasonable terms and conditions; adjudicate patent validity, enforceability, essentiality, and infringement; award monetary damages; and resolve any defenses and counterclaims. In jurisdictions where the failure to request a Prohibitive Order in a pleading waives the right to seek a Prohibitive Order at a later time, a Submitter may conditionally plead the right to seek a Prohibitive Order to preserve its right to do so later, if and when this policy's conditions for seeking, or seeking to enforce, a Prohibitive Order are met.

What is prohibited by the above policy clause? Under what circumstances is a SEP holder permitted to seek a Prohibitive Order against the implementer of an IEEE standard? What is the purpose of the final sentence of this policy language?

As noted above, the IEEE policy has been controversial. Who might have opposed the adoption of the clause shown above? On what basis? Do you think that the clause will have a positive or negative effect on standards-development at IEEE? Why?

\section{F. The Transfer of FRAND Commitments}

In Chapter 2, we considered issues arising from the assignment and transfer of intellectual property rights. In Chapter 11, we addressed the assignment and transfer of IP license rights. FRAND commitments raise a new set of issues: when a patent as to which a FRAND commitment has been made is transferred, what happens to that commitment? ${ }^{28}$ Does the commitment only

\footnotetext{
${ }^{28}$ This question is separate from the fate of licenses that have been executed in response to a FRAND commitment. Those licenses, as discussed in Chapter 11, likely continue following the transfer of the underlying patents. FRAND commitments, however, are commitments to enter into licenses, rather than licenses themselves.
} 
bind the firm that made the commitment, or does the commitment travel with the patent to bind its new owner? Absent specific language in the relevant SDO policy, the answer is less than clear.

This issue first received broad attention in connection with a patent covering part of IEEE's 802.3 Fast Ethernet standard. In 1994, the patent's original owner, National Semiconductor, committed to IEEE that it would license the patent for a flat fee of $\$ 1,000$ to any party implementing the standard. National Semiconductor later sold the patent, which was eventually acquired by Negotiated Data Solutions (N-Data), a PAE run by a former National Semiconductor attorney. N-Data announced that while it would license the patent on FRAND terms, it did not intend to honor National Semiconductor's original \$1,000 licensing offer. The FTC brought an action claiming that N-Data's disavowal of National Semiconductor's commitment constituted an unfair method of competition, as well as an unfair act or practice, in violation of Section 5 of the FTC Act (see Chapter 25). The case was settled with a consent decree pursuant to which N-Data agreed to honor National Semiconductor's original \$1,000 licensing commitment. ${ }^{29}$

The issue of transfers arose again in 2011, when bankrupt Nortel Networks, a contributor to several SDOs, proposed the sale of its assets, including approximately 4,000 patents, in a bankruptcy sale on a "free and clear" basis. ${ }^{30}$ Several product vendors, together with IEEE, argued that Nortel's "free and clear" sale could erase the patent licensing commitments that Nortel had previously made to SDOs including IEEE. Ultimately, the purchaser of the patents, a consortium including several large product vendors, voluntarily agreed to abide by Nortel's prior FRAND commitments and the issue was not adjudicated. ${ }^{31}$

Because the law remains unsettled in this regard, an increasing number of SDOs require participants that transfer SEPs as to which FRAND commitments have been made to ensure that those commitments are binding on subsequent owners of those SEPs. The policy approach adopted by IETF is shown below.

\footnotetext{
${ }^{29}$ Negotiated Data Solutions LLC, No. C-4234, 2008 WL 4407246 (F.T.C. Sept. 22, 2008).

${ }^{30}$ Under Section 363(f) of the U.S. Bankruptcy Code, a bankruptcy trustee or debtor in possession may sell the bankruptcy estate's assets "free and clear of any interest in such property." See Chapter 28 for a further discussion of bankruptcy issues in IP licensing transactions.

${ }^{31}$ In re Nortel Networks, Inc., 469 B.R. 478, 488 (Bankr. D. Del. 2012) (“On July 11, 2011, the Court entered an order approving the sale of Nortel's Residual Patent Assets, representing some 6,000 patents for telecommunications, internet, wireless, and other technology, to Rockstar Bidco, LP.”).
} 


\section{INTERNET ENGINEERING TASK FORCE}

\section{RFC 8179/BCP 79 - Intellectual Property Rights in IETF Technology (May 2017)}

5.5.c. It is likely that IETF will rely on licensing declarations and other information that may be contained in an IPR disclosure and that implementers will make technical, legal, and commercial decisions on the basis of such commitments and information. Thus, when licensing declarations and other information, comments, notes, or URLs for further information are contained in an IPR disclosure, the persons making such disclosure agree and acknowledge that the commitments and information contained in such disclosure shall be irrevocable and will attach, to the extent permissible by law, to the associated IPR, and all implementers of Implementing Technologies will be justified and entitled to rely on such materials in relating to such IPR, whether or not such IPR is subsequently transferred to a third party by the IPR holder making the commitment or providing the information. IPR holders making IPR disclosures that contain licensing declarations or providing such information, comments, notes, or URLs for further information must ensure that such commitments are binding on any transferee of the relevant IPR, and that such transferee will use reasonable efforts to ensure that such commitments are binding on a subsequent transferee of the relevant IPR, and so on.

\section{NOTES AND QUESTIONS}

1. A Non-Contested Policy. Unlike SDO policy amendments seeking to clarify the method of calculating FRAND royalties or limiting the ability of SDO members to seek injunctive relief, policy language requiring SEP licensing commitments to travel with transferred patents has not been particularly controversial. ${ }^{32}$ Why not? Are there parties that might not wish FRAND licensing commitments to continue after a SEP is transferred to a new owner?

2. The View from the Government. As noted above, the FTC brought an action against NData when it disavowed National Semiconductor's original SEP licensing commitment to IEEE. In 2012 and 2013, the FTC initiated actions against Motorola Mobility (then owned by Google) and Robert Bosch for similar reasons. ${ }^{33}$ Those actions also resulted in consent decrees. Officials from the DOJ and the European Commission have also encouraged SDOs to clarify that SEP licensing commitments travel with the underlying patents when they are transferred. Why are government enforcement agencies so interested in this topic? Why is this issue primarily addressed by antitrust and competition enforcement agencies rather than the legislature or other administrative agencies?

\footnotetext{
${ }^{32}$ For a discussion of contested versus non-contested SDO policy amendments, see Justus Baron, et al, Making the Rules: The Governance of Standard Development Organizations and their Policies on Intellectual Property Rights, JRC Science for Policy Report EUR 29655 at 157-58 (Mar. 2019).

${ }^{33}$ Statement of the Federal Trade Commission, Google Inc., F.T.C. File No. 121-0120 (F.T.C. Jan. 3, 2013); Statement of the Federal Trade Commission, Robert Bosch GmbH, F.T.C. File No. 121-0081 (F.T.C. Nov. 26, 2012).
} 
3. FRAND as Servitude? One theory that has been proposed in the literature is that FRAND commitments relating to SEPs can be analogized to real property servitudes (easements, covenants) that "run with the land". Thus, just as when a piece of real estate is sold, easements across that property continue to bind the new owner, FRAND commitments made with respect to a patent should continue to bind each successive owner of the patent. What do you think of this theory? Property-based analogies have not been embraced by courts assessing FRAND commitments. Why not? ${ }^{34}$

${ }^{34}$ For a discussion and critique of these theories, see Contreras, Market Reliance, supra note 7, at 536-38. 